\title{
Understanding sources of organic aerosol during CalNex-2010 using the CMAQ-VBS
}

\author{
Matthew C. Woody ${ }^{1}$, Kirk R. Baker ${ }^{1}$, Patrick L. Hayes ${ }^{2,3,4}$, Jose L. Jimenez ${ }^{3,4}$, Bonyoung Koo ${ }^{5}$, and Havala O. T. Pye ${ }^{1}$ \\ ${ }^{1}$ U.S. Environmental Protection Agency, Research Triangle Park, NC, USA \\ ${ }^{2}$ Université de Montréal, Department of Chemistry, Montreal, QC, Canada \\ ${ }^{3}$ Cooperative Institute for Research in Environmental Sciences (CIRES), University of Colorado, Boulder, CO, USA \\ ${ }^{4}$ Department of Chemistry and Biochemistry, University of Colorado, Boulder, CO, USA \\ ${ }^{5}$ Ramboll Environ International Corporation, Novato, CA, USA \\ Correspondence to: Havala O. T. Pye (pye.havala@epa.gov)
}

Received: 23 July 2015 - Published in Atmos. Chem. Phys. Discuss.: 5 October 2015

Revised: 11 February 2016 - Accepted: 15 March 2016 - Published: 29 March 2016

\begin{abstract}
Community Multiscale Air Quality (CMAQ) model simulations utilizing the traditional organic aerosol (OA) treatment (CMAQ-AE6) and a volatility basis set (VBS) treatment for OA (CMAQ-VBS) were evaluated against measurements collected at routine monitoring networks (Chemical Speciation Network (CSN) and Interagency Monitoring of Protected Visual Environments (IMPROVE)) and those collected during the 2010 California at the Nexus of Air Quality and Climate Change (CalNex) field campaign to examine important sources of OA in southern California.
\end{abstract}

Traditionally, CMAQ treats primary organic aerosol (POA) as nonvolatile and uses a two-product framework to represent secondary organic aerosol (SOA) formation. CMAQ-VBS instead treats POA as semivolatile and lumps OA using volatility bins spaced an order of magnitude apart. The CMAQ-VBS approach underpredicted organic carbon (OC) at IMPROVE and CSN sites to a greater degree than CMAQ-AE6 due to the semivolatile POA treatment. However, comparisons to aerosol mass spectrometer (AMS) measurements collected at Pasadena, CA, indicated that CMAQ-VBS better represented the diurnal profile and primary/secondary split of OA. CMAQ-VBS SOA underpredicted the average measured AMS oxygenated organic aerosol (OOA, a surrogate for SOA) concentration by a factor of 5.2, representing a considerable improvement to CMAQAE6 SOA predictions (factor of 24 lower than AMS).

We use two new methods, one based on species ratios (SOA / $\triangle \mathrm{CO}$ and SOA $/ \mathrm{O}_{x}$ ) and another on a simplified
SOA parameterization, to apportion the SOA underprediction for CMAQ-VBS to slow photochemical oxidation (estimated as $1.5 \times$ lower than observed at Pasadena using $\left.-\log \left(\mathrm{NO}_{x}: \mathrm{NO}_{y}\right)\right)$, low intrinsic SOA formation efficiency (low by 1.6 to $2 \times$ for Pasadena), and low emissions or excessive dispersion for the Pasadena site (estimated to be 1.6 to $2.3 \times$ too low/excessive). The first and third factors are common to CMAQ-AE6, while the intrinsic SOA formation efficiency for that model is estimated to be too low by about $7 \times$.

From source-apportioned model results, we found most of the CMAQ-VBS modeled POA at the Pasadena CalNex site was attributable to meat cooking emissions (48\%, consistent with a substantial fraction of cooking OA in the observations). This is compared to $18 \%$ from gasoline vehicle emissions, $13 \%$ from biomass burning (in the form of residential wood combustion), and $8 \%$ from diesel vehicle emissions. All "other" inventoried emission sources (e.g., industrial, point, and area sources) comprised the final $13 \%$. The CMAQ-VBS semivolatile POA treatment underpredicted AMS hydrocarbon-like OA (HOA) + cookinginfluenced OA (CIOA) at Pasadena by a factor of $1.8 \mathrm{com}$ pared to a factor of 1.4 overprediction of POA in CMAQAE6, but it did capture the AMS diurnal profile of HOA and CIOA well, with the exception of the midday peak.

Overall, the CMAQ-VBS with its semivolatile treatment of POA, SOA from intermediate volatility organic compounds (IVOCs), and aging of SOA improves SOA model performance (though SOA formation efficiency is still 1.6- 
$2 \times$ too low). However, continued efforts are needed to better understand assumptions in the parameterization (e.g., SOA aging) and provide additional certainty to how best to apply existing emission inventories in a framework that treats POA as semivolatile, which currently degrades existing model performance at routine monitoring networks. The VBS and other approaches (e.g., AE6) require additional work to appropriately incorporate IVOC emissions and subsequent SOA formation.

\section{Introduction}

Organic matter, comprised of primary organic aerosols (POA) and secondary organic aerosols (SOA), is a ubiquitous component of $\mathrm{PM}_{2.5}$. For example, the Los Angeles South Coast Air Basin and San Joaquin Valley are designated as $\mathrm{PM}_{2.5}$ nonattainment areas (http://www.epa.gov/oaqps001/ greenbk/ancl.html), and major ground sites for the California at the Nexus of Air Quality and Climate Change (CalNex) campaign (Ryerson et al., 2013) were located within these basins at Pasadena and Bakersfield, respectively. Fortyone percent of the submicron aerosol mass at Pasadena was organic during CalNex (Hayes et al., 2013), and several complementary measurements of the organics including radiocarbon, SOA tracers, OC / EC, organic aerosol (OA) composition, and volatile organic compounds (VOCs) (Zotter et al., 2014; Baker et al., 2015; Hayes et al., 2013) were collected.

Measurements have shown SOA is expected to be comparable to or dominate over POA, even in urban areas close to emission sources (Zhang et al., 2007). Average OA O : C ratios exceed 0.3 in southern California (Craven et al., 2013), suggesting significant contributions from SOA, and over $70 \%$ of midday OA is estimated to be secondary in Riverside, CA (Docherty et al., 2008), Mexico City (Aiken et al., 2009), and Pasadena, CA (Hersey et al., 2011; Hayes et al., 2013).

However, models tend to underestimate anthropogenic SOA from both known and unknown VOC precursors (Ensberg et al., 2014; Jathar et al., 2014; Zhang et al., 2014). The Community Multiscale Air Quality (CMAQ) model (Byun and Schere, 2006), which is used for research and regulatory purposes, also tends to underpredict SOA in anthropogenically dominated locations (Foley et al., 2010; Baker et al., 2015). In CMAQ, POA is normally treated as nonvolatile (Simon and Bhave, 2012), and SOA forms mostly from gasphase VOC oxidation to form lower-volatility products with contributions from cloud processing (Carlton et al., 2010). Simulations using this traditional OA treatment in CMAQ (CMAQ-AE6) during CalNex (Baker et al., 2015) indicate that predicted OA is dominated by POA with a small contribution of SOA from aromatic and biogenic VOC oxidation in contrast to the SOA dominated picture from observations. While anthropogenic parent VOCs are well repre- sented in the model, secondary organic carbon (SOC) from aromatics is underestimated (Baker et al., 2015). The model is likely missing sources of fossil carbon and tracer-based apportionment methods for SOC are unable to capture the total OA concentration. Hayes et al. (2015) indicated the SOA formed from the oxidation of VOCs alone is insufficient to explain observed SOA, and primary semivolatile organic compounds (SVOCs)/intermediate volatility organic compounds (IVOCs) are likely needed to explain the observed mass.

In recognizing the potential role for S/IVOC emissions to form SOA (Robinson et al., 2007; Dzepina et al., 2009; Ahmadov et al., 2012), we employ the publicly available version of the CMAQ-VBS model (Koo et al., 2014) and compare it to the standard nonvolatile POA and SOA from VOCs in CMAQ v5.0.2, with a focus on the 2010 CalNexLA site in Pasadena, CA. Our analysis focuses on the degree to which processes and/or sources characterized in CMAQ v5.0.2 may be responsible for OA observed as part of CalNex. We also identify whether underestimates in OA from CMAQ are due to emissions/dispersion, photochemical processing, or the OA treatment.

\section{Methodology}

\subsection{Model application}

The CMAQ model version 5.0.2 was applied to estimate air quality in California from 4 May to 30 June 2010, which coincides with the CalNex campaign (May and July 2010). Gas-phase chemistry was simulated with the Carbon Bond 2005 (CB05) chemical mechanism (Yarwood et al., 2005). Aerosols were simulated using the traditional aerosol 6 (AE6) module (CMAQ-AE6) and an alternative version of AE6 which uses the volatility basis set (VBS) approach (Donahue et al., 2006) to model OA (CMAQ-VBS).

The model domain covered California and Nevada with a $4 \mathrm{~km}(317 \times 236)$ grid resolution (Fig. 1$)$. The vertical domain included 34 layers and extended to $50 \mathrm{mb}$. The first 11 days of the simulation were treated as a spin-up and results were excluded from the analysis to minimize the influence of initial conditions.

\subsection{CMAQ-VBS OA treatment}

Details of the VBS treatment of organics in CMAQ are described in Koo et al. (2014) and comparisons of the POA and SOA treatments in the traditional CMAQ-AE6 and CMAQVBS and provided in the Supplement (Tables S1 and S2 in the Supplement). Briefly, CMAQ-VBS includes four distinct basis sets/OA groups: primary anthropogenic (corresponding to hydrocarbon-like OA (HOA) or POA), secondary anthropogenic (anthropogenic SOA), secondary biogenic (biogenic SOA), and primary biomass burning (biomass burning OA). Each of the four basis sets is represented using five bins. 


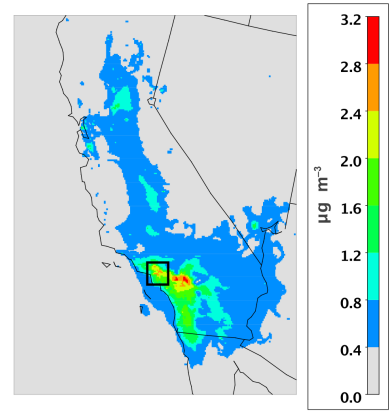

(a) Total OA

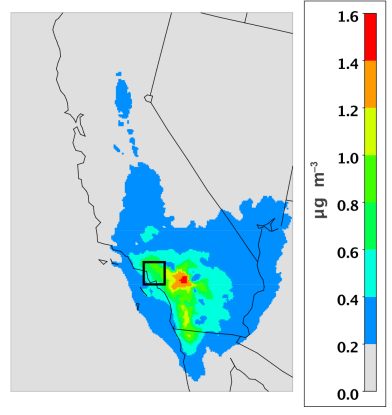

(c) Anthropogenic SOA

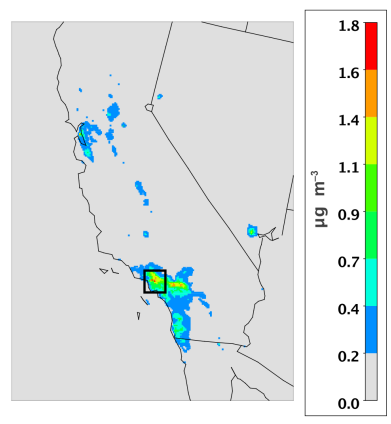

(b) POA

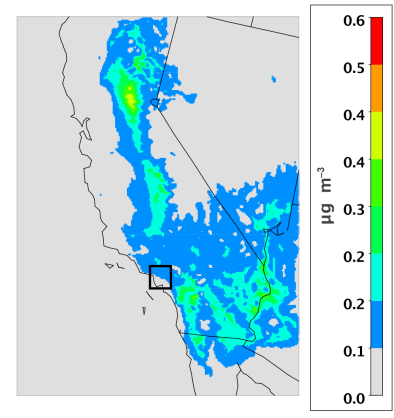

(d) Biogenic SOA
Figure 1. CMAQ-VBS modeling period average (15 May to 30 June 2010) concentrations of total OA (a), primary organics (b), anthropogenic SOA (c), and biogenic SOA (d). The black box indicates the approximate location of Downtown Los Angeles and Pasadena. Note each plot uses a unique scale.

Four bins are used to represent $C^{*}$ values ranging from $10^{0}$ to $10^{3} \mu \mathrm{g} \mathrm{m}^{-3}$ and one bin $\left(C^{*}=0\right.$, which at typical ambient conditions at Pasadena would represent compounds with $C^{*} \leq 10^{-1} \mu \mathrm{g} \mathrm{m}^{-3}$ ) represents nonvolatile particles.

Traditional CMAQ-AE6 nonvolatile POA is replaced in CMAQ-VBS with semivolatile POA, referred to here as primary SVOCs, comprised of primary gas- and particlephase organics located in the primary anthropogenic basis set. In this framework, CMAQ-VBS POA is therefore primary SVOCs located in the particle phase. Primary SVOCs are aged/oxidized in the gas phase by reactions with $\mathrm{OH}$ using a rate constant of $4 \times 10^{-11} \mathrm{~cm}^{3} \mathrm{molec}^{-1} \mathrm{~s}^{-1}$ (Robinson et al., 2007), with each oxidation step lowering volatility by an order of magnitude and a portion $(\sim 10 \%)$ of the OA mass shifted from the primary SVOC (POA) to the secondary SVOC (SOA) set (Koo et al., 2014). The transfer of oxidized primary SVOCs (i.e., POA) to secondary SVOCs (i.e., SOA) is used as a modeling technique to maintain accurate $\mathrm{O}: \mathrm{C}$ ratios. This feature of the 1.5-D VBS (Koo et al., 2014) uses existing POA and SOA basis sets to avoid additional computational burden of added model species (e.g., oxidized POA basis set). With this treatment, the majority $(\sim 90 \%)$ of slightly aged POA (after a single aging reaction) resides as POA-like while very aged POA (after four aging reactions) would reside as two-thirds POA and one-third SOA. We acknowledge that this approach, which prioritizes $\mathrm{O}: \mathrm{C}$ ratios, adds uncertainty when model results are compared against aerosol mass spectrometry (AMS) measurements and is an area where future research is needed to better understand that uncertainty. At Pasadena, our model predictions indicated $\sim 8 \%$ of modeled OA was comprised of oxidized POA and suggests this approach has only a small impact in this application.

CMAQ-VBS also includes a formation pathway of SOA from the oxidation of IVOC emissions, where IVOCs represent gas-phase compounds with volatilities between SVOCs and VOCs $\left(C^{*}\right.$ values ranging from $10^{4}$ to $\left.10^{6} \mu \mathrm{g} \mathrm{m}{ }^{-3}\right)$. Most of these compounds are generally considered to either be missing from emission inventories entirely or mischaracterized as non-SOA forming compounds. The inclusion of IVOCs represents an additional SOA precursor mass introduced into the model relative to CMAQ-AE6. OH is artificially recycled (i.e., not depleted) in oxidation reactions of IVOCs and SVOCs (primary and secondary) to prevent double counting and impacts to the gas-phase chemistry of the underlying chemical mechanism as these species are likely already represented in the model (e.g., paraffins, olefins, nonreactive). This technique is identical to that used by a number of existing CMAQ SOA precursors (e.g., benzene and sesquiterpene) in $\mathrm{CB} 05$.

CMAQ-VBS semivolatile SOA is represented using secondary SVOCs (gas and particle phase) located in the secondary anthropogenic and biogenic basis sets. SOA yields from VOC precursors are the same as those used in Murphy and Pandis (2009) except for toluene (Hildebrandt et al., 2009). SOA yields from IVOC precursors are based on the Murphy and Pandis (2009) yields for the SAPRC ARO2 model species. ARO2 was used because it represents naphthalene (among other compounds), where naphthalene has previously been used as a surrogate to represent IVOCs (Pye and Seinfeld, 2010). Photochemical reactions producing condensable vapors from aromatics (toluene, xylene, and benzene), isoprene, and monoterpenes utilize distinct high- and low- $\mathrm{NO}_{x}$ yields (determined using $\mathrm{RO}_{2}+\mathrm{NO}$ or $\mathrm{RO}_{2}+\mathrm{HO}_{2}$ ) while sesquiterpenes and IVOCs do not (IVOC $\mathrm{NO}_{x}$ dependence excluded due to a lack of experimental data).

While experimental data suggest that aging of both anthropogenic SOA (Hildebrandt et al., 2009) and biogenic SOA (Donahue et al., 2012) occurs, in CMAQ-VBS only anthropogenic SOA (formed from both VOCs and IVOCs) is aged via reactions of the gas-phase semivolatiles with $\mathrm{OH}$ using a rate constant of $2 \times 10^{-11} \mathrm{~cm}^{3} \mathrm{molec}^{-1} \mathrm{~s}^{-1}$ (twice the rate previously assumed for anthropogenic SOA aging; Murphy and Pandis, 2009) and based on results from the 2-D VBS (Donahue et al., 2013). Anthropogenic aging reactions form products with a vapor pressure reduced by 1 order of magnitude $(10 \times)$ for each oxidation step. Biogenic aging is turned off in CMAQ-VBS by default as previous results, us- 
ing a more conservative aging scheme than in CMAQ-VBS, indicated the VBS overpredicted OA in rural areas when biogenic SOA was aged (Lane et al., 2008; Murphy and Pandis, 2009; Fountoukis et al., 2011). In recognizing that the aging of biogenic SOA does occur, we perform a sensitivity simulation that includes secondary biogenic SVOC aging reactions, the results of which are presented in Sect. 3.4.2. In excluding aging of secondary biogenic SVOCs in all but our sensitivity simulation, we effectively assume that the net result of functionalization (aging) and fragmentation, an important process for accurate predictions of biogenic SOA (Donahue et al., 2012), does not increase biogenic SOA concentrations (Fountoukis et al., 2011).

\subsection{Emissions}

United States anthropogenic emissions were based on version 1 of the 2011 National Emissions Inventory (NEI) (US Environmental Protection Agency, 2014a). Stationary point sources reporting continuous emissions monitor data were modeled with day- and hour-specific emissions matching the simulation period. Wildfire emissions were day-specific although have little impact in Pasadena during this time period (Bahreini et al., 2012; Hayes et al., 2013). Biogenic emissions were day- and hour-specific using Weather Research Forecast (WRF) model temperature and solar radiation as input to the Biogenic Emission Inventory (BEIS) version 3.14 model (Carlton and Baker, 2011). Anthropogenic emissions from Mexico were projected to 2010 from 1999 (US Environmental Protection Agency, 2014b). All emissions were processed for input to CMAQ using the Sparse Matrix Operator Kernel Emissions (SMOKE) modeling system (Houyoux et al., 2000).

CMAQ-VBS internally estimates SVOC and IVOC emissions at runtime based on traditional POA emission inventories. In the configuration used here, SVOC emissions are equivalent to the POA emissions input, i.e., no scaling of POA is applied to calculate SVOC emissions. We base this on the assumption that NEI POA measurements are made at high concentrations and therefore all SVOCs are partitioned to the particle phase. Therefore, the total mass of SVOC (gas- and particle-phase) emissions are equal to traditional POA emissions. IVOC emissions are estimated as $1.5 \times$ SVOCs (Robinson et al., 2007), or $1.5 \times$ the traditional POA emission inventory. Although most modeling studies set IVOCs $=1.5 \times \mathrm{SVOCs}$, the total amount of material introduced into the model varies depending on the study and leads to varying importance of SOA from S/IVOCs vs. VOCS in different simulations. For example, in the box modeling studies of Dzepina et al. (2009) and Hayes et al. (2015) the POA was set equal to the measured HOA, the SVOCs were calculated from equilibrium partitioning using the Robinson et al. (2007) volatility distribution, and then IVOC were set to $1.5 \times$ SVOC. In grid-based model studies examining Mexico City OA (Hodzic et al., 2010; Tsimpidi
Table 1. CMAQ-VBS volatility distribution of POA emissions from gasoline vehicles, diesel vehicles, biomass burning, nonvolatile (e.g., fugitive dust), meat cooking, and "other" sources.

\begin{tabular}{|c|c|c|c|c|c|}
\hline Source & Nonvolatile $^{\mathrm{a}}$ & $10^{0}$ & $10^{1}$ & $10^{2}$ & $10^{3}$ \\
\hline Gas vehicles $(\mathrm{GV})^{\mathrm{b}}$ & 0.27 & 0.15 & 0.26 & 0.15 & 0.17 \\
\hline Diesel vehicles $(\mathrm{DV})^{\mathrm{c}}$ & 0.03 & 0.25 & 0.37 & 0.24 & 0.11 \\
\hline Biomass burning $(\mathrm{BB})^{\mathrm{d}}$ & 0.20 & 0.10 & 0.10 & 0.20 & 0.40 \\
\hline Nonvolatile (NV) & 1.00 & 0.00 & 0.00 & 0.00 & 0.00 \\
\hline Meat cooking $(\mathrm{MC})^{\mathrm{e}}$ & 0.35 & 0.35 & 0.10 & 0.10 & 0.10 \\
\hline Other $(\mathrm{OP})^{\mathrm{f}}$ & 0.09 & 0.09 & 0.14 & 0.18 & 0.50 \\
\hline
\end{tabular}

et al., 2010; Shrivastava et al., 2011), the POA emission inventory was assumed to represent the fraction of aerosol remaining after evaporation of semivolatile emissions based on comparisons with observations; therefore SVOC emissions were set to $3 \times$ traditional POA emissions and IVOC emissions were set to $1.5 \times$ SVOC emissions, leading to a total of $\mathrm{S} / \mathrm{IVOC}=7.5$ traditional POA. Therefore, modeled S/IVOC emissions can range from 2.5 to $7.5 \times$ existing POA inventories to match measurements (which makes direct comparisons to existing inventories difficult) and remain a source of uncertainty in conducting and comparing models that include S/IVOCs.

The volatility split of SVOC emissions in CMAQ-VBS is provided in Table 1. By default, CMAQ-VBS assigns volatility distributions for POA emissions from gasoline vehicles, diesel vehicles, biomass burning, nonvolatile sources, and "other" sources (e.g., point, industrial, and area sources). In the absence of source-specific POA emissions, the "other" profile is used. In our application, a significant portion of POA was associated with meat cooking activities (Table 2), which thermodenuder data suggest is of lower volatility compared to the other CMAQ-VBS source-specific POA categories (Huffman et al., 2009). We approximated a new volatility distribution for meat cooking SVOC emissions (Table 1) based on comparisons of meat cooking and the MILAGRO average biomass burning thermodenuder-measured volatility (Huffman et al., 2009). This is meant as a first approximation and represents an area where further research is needed. We note that thermodenuder data provide some constraints on SVOCs but no constraints on IVOCs; therefore the IVOC emissions from meat cooking remained unchanged (1.5 $\times$ of meat cooking POA emissions).

\subsection{Sensitivity simulations}

In addition to evaluating the publicly available version of CMAQ-VBS, we performed a number of sensitivity simulations to examine the importance of OA sources in the model. For example, after input into CMAQ-VBS, anthropogenic POA emission source specificity is lost as anthropogenic 
Table 2. Domain and modeling period (4 May to 30 June 2010) total 2011 NEI POA emissions (tons) for gasoline vehicles, diesel vehicles, biomass burning, nonvolatile (e.g., fugitive dust), meat cooking, and "other" sources.

\begin{tabular}{lr}
\hline Source & Emissions (t) \\
\hline Gas vehicles (GV) & 1990 \\
Diesel vehicles (DV) & 800 \\
Biomass burning (BB) & 8550 \\
Nonvolatile (NV) & 540 \\
Meat cooking (MC) & 1470 \\
Other (OP) & 2070 \\
\hline
\end{tabular}

POA is lumped into a single basis set. In order to leverage our source-specific emission inputs, basis sets for POA from gasoline vehicles, diesel vehicles, and meat cooking activities were added to provide anthropogenic POA source apportionment (Sect. 3.4.1).

To evaluate how model predictions change with varying S/IVOC emissions, sensitivity simulations were conducted with primary SVOC emissions scaled by $1.5 \times, 2 \times$, and $3 \times$ the NEI POA mass (Sects. 3.2.2 and 3.2.3). In each case, IVOC emissions were $1.5 \times$ of SVOC emissions, corresponding to factors of $2.25 \times, 3 \times$, and $4.5 \times$ NEI POA mass. The range of values are based on an assumption that the POA inventory is estimated before $(3 \times)$ or after $(1 \times)$ partitioning at ambient conditions $\left(\sim 30 \mu \mathrm{g} \mathrm{m}^{-3}\right)$ and represents lower and upper bounds of scaling factors used in previous studies (e.g., Robinson et al., 2007; Dzepina et al., 2009).

Another set of sensitivity simulations quantified VBS SOA contributions from first-product oxidation of VOCs (i.e., no aging), anthropogenic and biogenic SVOC aging, and IVOCs (Sect. 3.4.2). In sensitivity simulations with aging of secondary biogenic SVOCs we also quantified in-basin vs. outof-basin contributions at Pasadena from biogenic SOA precursor emissions by removing LA basin biogenic SOA precursors.

Lastly, given the tendency for regional air quality studies (Volkamer et al., 2006; De Gouw et al., 2008), including CMAQ (Foley et al., 2010; Baker et al., 2015), to underpredict anthropogenic SOA in urban areas, we evaluated a simplified SOA parameterization (SIMPLE) (Hodzic and Jimenez, 2011; Hayes et al., 2015). SIMPLE represents an alternative SOA modeling approach to the CMAQ-AE6 and CMAQ-VBS SOA treatments (Sect. 3.4.3) and has been shown to perform well for SOA predictions at Pasadena (Hayes et al., 2015) and for OA predictions in the southeastern USA (Kim et al., 2015).

\subsection{Meteorology, boundary, and initial conditions}

Gridded meteorological variables used for input to CMAQ and SMOKE were generated using version 3.1 of the WRF model, Advanced Research WRF core (Skamarock and
Klemp, 2008). Details regarding the WRF configuration and application are provided elsewhere (Baker et al., 2013). In general, surface meteorology and daytime mixing layer heights were well represented for this period in California. A $36 \mathrm{~km}$ CMAQ simulation covering the continental United States for the same time period was used to generate boundary conditions for this simulation. A global GEOS-CHEM (v8-03-02) (Bey et al., 2001) simulation provided boundary inflow for the $36 \mathrm{~km}$ continental-scale CMAQ simulation (Henderson et al., 2014). Neither larger-scale simulation included CMAQ-VBS OA species, though the impact is likely small as a CMAQ-AE6 sensitivity simulation indicated most $(99 \%)$ of the OA at Pasadena originates from local or regional sources located in our modeling domain.

\subsection{Measurements}

Ground-based CalNex measurements were collected in Pasadena, CA, from 15 May to 15 June 2010 (Ryerson et al., 2013). The Pasadena sampling site was located on the California Institute of Technology campus, northeast of the Los Angeles metropolitan area and south of the San Gabriel Mountains. Both filter-based carbon measurements and AMS PM measurements were collected at this site. The filter-based measurements provide $23 \mathrm{~h}$ average concentrations of organic carbon, elemental carbon, and total carbon as well as the non-fossil vs. fossil carbon fraction. When compared against the filter-based and routine monitoring network (Chemical Speciation Network (CSN) and Interagency Monitoring of Protected Visual Environments (IMPROVE)) measurements of OC, CMAQ-VBS OA is converted to OC using OA / OC ratios reported in Koo et al. (2014). Additional details of the filter-based measurements, including comparisons of those measurements against traditional CMAQ (CMAQAE6) results, can be found in Baker et al. (2015). The AMS data provide real-time (sub-hourly) measurements of speciated sub-micron PM, including various organic components as determined using positive matrix factorization (PMF). The AMS organic components resolved at the site include two types of SOA (semivolatile oxygenated OA (SV-OOA) consistent with fresher SOA mostly from urban areas, and lowvolatility oxygenated OA (LV-OOA) consistent with aged SOA), two types of POA HOA and cooking-influenced OA (CIOA)), and local OA (LOA). The source of LOA, which accounts for approximately $5 \%$ of OA mass at Pasadena, is generally unknown, though large fluctuations in measured concentrations suggest a local source (Hayes et al., 2013). When comparisons using both AMS and the filter-based OC measurements are made, AMS OA is converted to OC using OA / OC ratios reported in Hayes et al. (2013). Additional details regarding the AMS measurements and PMF component analysis can be found in Hayes et al. (2013). 
Table 3. CMAQ-VBS and CMAQ-AE6 organic carbon (OC) and elemental carbon (EC) model predictions evaluated against routine model-

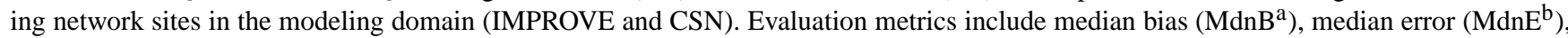
normalized median bias $\left(\mathrm{NMdnB}^{\mathrm{c}}\right)$, and normalized median error $\left(\mathrm{NMdnE}^{\mathrm{d}}\right)$.

\begin{tabular}{llrrrrrr}
\hline $\begin{array}{l}\text { OA treatment/ } \\
\text { species }\end{array}$ & Network & $\begin{array}{r}\text { Mean obs. } \\
\left(\mu \mathrm{g} \mathrm{m}^{-3}\right)\end{array}$ & $\begin{array}{r}\text { Mean model } \\
\left(\mu \mathrm{g} \mathrm{m}^{-3}\right)\end{array}$ & $\begin{array}{r}\mathrm{MdnB} \\
\left(\mu \mathrm{g} \mathrm{m}^{-3}\right)\end{array}$ & $\begin{array}{r}\text { MdnE } \\
\left(\mu \mathrm{g} \mathrm{m}^{-3}\right)\end{array}$ & $\begin{array}{r}\text { NMdnB } \\
(\%)\end{array}$ & $\begin{array}{r}\text { NMdnE } \\
(\%)\end{array}$ \\
\hline CMAQ-VBS & IMPROVE (247) & 0.71 & 0.23 & -0.38 & 0.38 & -63.9 & 64.6 \\
OC & CSN (159) & 1.26 & 0.75 & -0.31 & 0.44 & -25.5 & 36.5 \\
\hline CMAQ-AE6 & IMPROVE (247) & 0.71 & 0.29 & -0.33 & 0.34 & -55.7 & 57.6 \\
OC & CSN (159) & 1.26 & 1.22 & 0.12 & 0.71 & 9.9 & 43.9 \\
\hline CMAQ-VBS & IMPROVE (249) & 0.10 & 0.09 & -0.02 & 0.03 & -20.3 & 40.8 \\
EC & CSN (159) & 0.33 & 0.58 & 0.24 & 0.26 & 81.4 & 87.7 \\
\hline CMAQ-AE6 & IMPROVE (249) & 0.10 & 0.10 & -0.01 & 0.03 & -13.4 & 40.1 \\
EC & CSN (159) & 0.33 & 0.60 & 0.25 & 0.27 & 83.3 & 89.4 \\
\hline
\end{tabular}

${ }^{\mathrm{a}} \mathrm{MdnB}=\operatorname{median}(\operatorname{model}-\mathrm{obs})_{N} \cdot{ }^{\mathrm{b}} \mathrm{MdnE}=\operatorname{median}(\mid \text { model }-\mathrm{obs} \mid)_{N} \cdot{ }^{\mathrm{c}} \mathrm{NMdnB}=\frac{\text { median }(\text { model }-\mathrm{obs})}{\text { median }_{N}(\mathrm{obs})} \times \mathbf{N} \times 100 \%$.

${ }^{\mathrm{d}} \mathrm{NMdnE}=\frac{\text { median }(|\operatorname{model}-\mathrm{obs}|)_{N}}{\text { median }(\mathrm{obs}) N} \times 100 \%$.

\section{Results and discussion}

\subsection{Comparison against routine monitoring networks}

Average OA concentrations predicted by CMAQ-VBS during 15 May to 30 June were highest in the Greater Los Angeles Area where the domain maximum concentration was $3.1 \mathrm{~g} \mathrm{~m}^{-3}$ (Fig. 1). In this region, OA was approximately $30-50 \%$ of total modeled $\mathrm{PM}_{2.5}$ and was generally evenly split between primary and secondary (i.e., SOA comprised $40-60 \%$ of OA). In contrast, CMAQ-AE6 predicted the majority (80-90\%) of OA was comprised of POA in LA. The shift from primary dominated to a more even primary/secondary split in CMAQ-VBS is due to both the semivolatile treatment of POA (lowering POA concentrations) and additional SOA formation pathways (SOA from IVOCs and SOA aging as discussed in Sect. 3.4.2).

Model performance comparisons at IMPROVE and CSN sites in California and Nevada indicated CMAQ-VBS underpredicted OC (Table 3). Model performance for OC was slightly degraded (i.e., greater underprediction) compared to CMAQ-AE6 predictions (Table 3). While CMAQ-VBS predicted higher concentrations of SOA due to additional SOA formation pathways (see Table S2 in the Supplement), including the introduction of IVOCs mass into the modeling system, the additional SOA production did not compensate enough for the evaporated POA resulting in degraded performance relative to routine network measurements.

The degraded OC model performance (with the exception of slightly improved error) was more evident at CSN sites, which are often located closer to anthropogenic emission sources. At those sites, CMAQ-AE6 OC normalized median bias (NMdnB) and error (NMdnE) were 9.9 and $43.9 \%$ compared to -25.5 and $36.5 \%$ in CMAQ-VBS. At IMPROVE sites, CMAQ-AE6 NMdnB and NMdnE (-55.7 and 57.6\%) were comparable to CMAQ-VBS values (-63.9 and 64.6\%), with the negative bias indicating both consistently underpredicted OC.

CMAQ-VBS also underpredicted OC compared to filterbased and AMS measurements at the Pasadena CalNex site, (Fig. 2). CMAQ-VBS OC predictions were approximately 2 to $3 \times$ lower than measured $\mathrm{OC}$, with the largest differences in modeled to measured OA mass generally occurring during photochemically active periods (e.g., 4 to 7 June) when OOA concentrations were higher (Fig. 3), suggesting the model underpredicts SOA.

\subsection{Comparison against CalNex measurements at Pasadena}

Figures 3 and 4 compare CMAQ-VBS results against AMSmeasured submicron OA PMF components, where CMAQVBS POA from meat cooking sources was compared against AMS CIOA, CMAQ-VBS POA from all other sources including motor vehicles (referred to here as non-cooking POA or ncPOA) was compared against AMS HOA, and CMAQVBS SOA was compared against AMS SV-OOA + LV-OOA. Additional AMS measurements of LOA and CMAQ-VBS biomass burning OA from residential wood combustion are included in Fig. 4, but these measurements/model results do not have a direct corresponding AMS/model value.

\subsubsection{Meat cooking OA}

CMAQ-VBS CIOA concentrations averaged $0.65 \mu \mathrm{g} \mathrm{m}^{-3}$ (28\% of modeled OA) at Pasadena during the modeling period with a diurnal profile that was generally flat throughout the day and peaked at night. This is compared to an average AMS CIOA concentration of $1.22 \mu \mathrm{g} \mathrm{m}^{-3}$ (17\% of measured OA) and a diurnal profile 


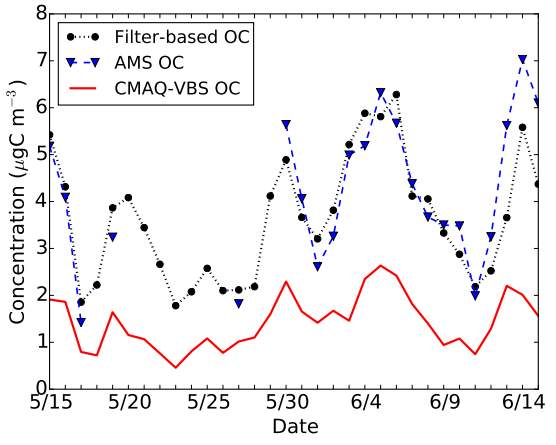

(a) 23-hour average OC

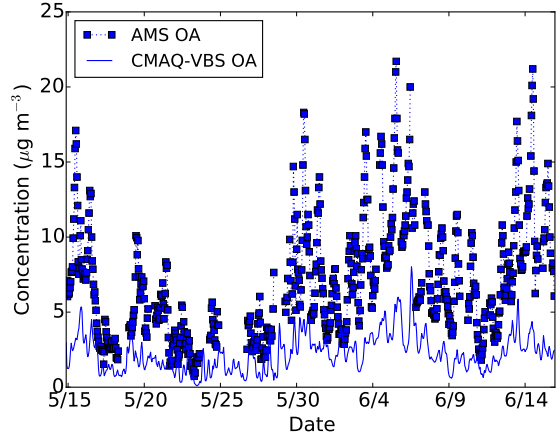

(b) Hourly OA

Figure 2. (a) Modeled and measured (EPA filter-based and AMS) $23 \mathrm{~h}$ average OC and (b) hourly modeled and AMS-measured OA at Pasadena. AMS measurements in (a) were converted to OC using OM to OC ratios reported in Hayes et al. (2013) and include only days with $>16$ hourly measurements (i.e., 18, 20-26, 28, and 29 May are excluded due to missing measurements).
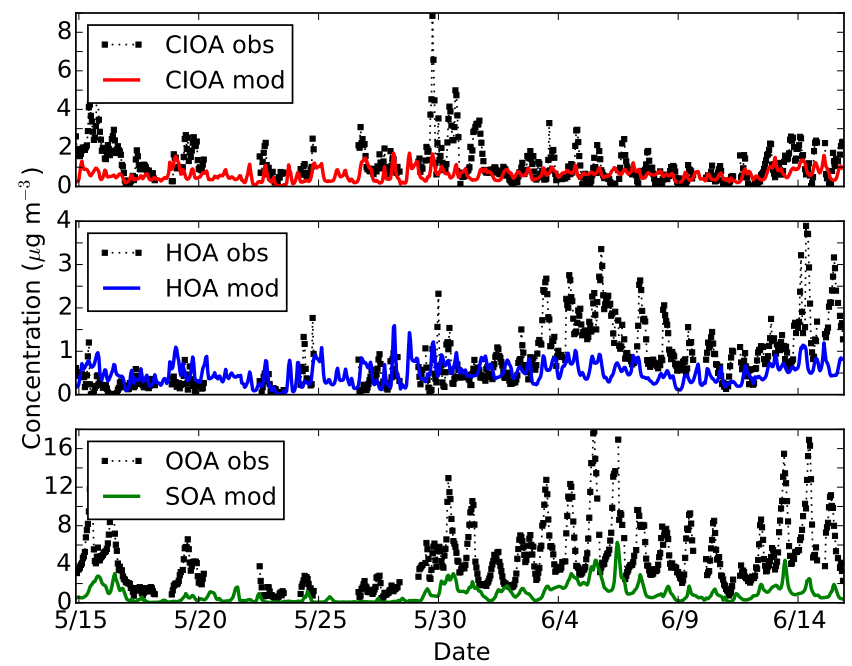

Figure 3. Hourly AMS-measured (CIOA obs) and CMAQ-VBS predicted (CIOA mod) meat cooking POA (top), hydrocarbon-like OA (HOA) and ncPOA (middle), and OOA (SV-OOA + LV-OOA) and SOA (bottom) at Pasadena.

that peaked in the afternoon and at night, slightly later than typical mealtimes and likely due to transport time (Hayes et al., 2013). The AMS diurnal profile at Pasadena is consistent with AMS measurements from several major urban areas, including Barcelona, Beijing, London, Manchester, New York City, and Paris (Allan et al., 2010; Huang et al., 2010; Sun et al., 2011; Mohr et al., 2012; Freutel et al., 2013). CMAQ-VBS generally compared well to AMS measurements in the morning but underpredicted the afternoon peak by $3.8 \times$ and evening peak by $2.8 \times$.

To determine whether partitioning alone explained the underprediction in modeled midday CIOA concentrations, we considered two potential scenarios. In the first scenario, we removed model OA bias by replacing modeled OA with AMS-measured OA and then calculated the theoretical par- titioning of modeled semivolatile CIOA vapors. Using the higher AMS OA concentrations, more semivolatile CIOA vapors partitioned to the particle phase and increased modeled CIOA concentrations by approximately $10 \%$ in the afternoon. In the second scenario, we treated the modeled CIOA as nonvolatile (100\% of emissions in the particle phase). Model concentrations increased by $30-40 \%$ and generally improved model performance $(-32 \%$ normalized median bias compared to $-51 \%$ in the semivolatile treatment). However, the modeled CIOA still underpredicted the afternoon and evening peaks by $2.9 \times$ and $2 \times$, respectively.

Even a nonvolatile treatment was unable to reproduce the measured peaks, suggesting the model CIOA emissions were low, particularly during afternoon and evening hours. This is expected since the 2011 emission inventory excludes residential meat cooking and the inclusion of these emissions would ameliorate some of the underprediction bias in evening hours and on weekends. To account for missing residential meat cooking emissions and potential underestimates in commercial meat cooking emissions, a doubling of CIOA emissions did well to reproduce the averaged measured value (1.28 $\mu \mathrm{g} \mathrm{m}^{-3}$ modeled vs. $1.22 \mu \mathrm{g} \mathrm{m}^{-3}$ measured). However, the diurnal profile applied in SMOKE to the majority of CIOA emissions (profile 26) is a low-arcing profile that peaks at 15:00 LST (see Fig. S1 in the Supplement). Additional mass of emissions applied to this profile helped to capture average CIOA and improved underpredictions of the evening peak (lowered from $2.8 \times$ to $1.3 \times$ ) but overpredicted measurements in the morning and maintained the underprediction of afternoon AMS-measured CIOA (Fig. S2), suggesting some morning emissions should be reallocated to occur in the afternoon. It is also possible that some of the measured CIOA peak was due to photochemistry, as the afternoon peak coincides with the peak in AMS SV-OOA.

The highest observed CIOA value $\left(8.9 \mu \mathrm{g} \mathrm{m}^{-3}\right)$ occurred on 30 May at 20:00 LST, which corresponds to the Saturday of the Memorial Day weekend. Results from Zotter 


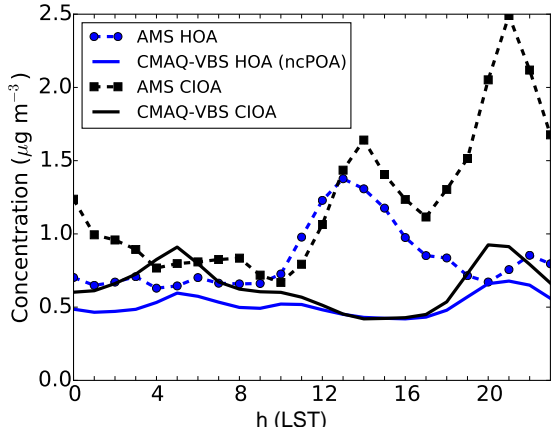

(a) CMAQ-VBS Primary-like

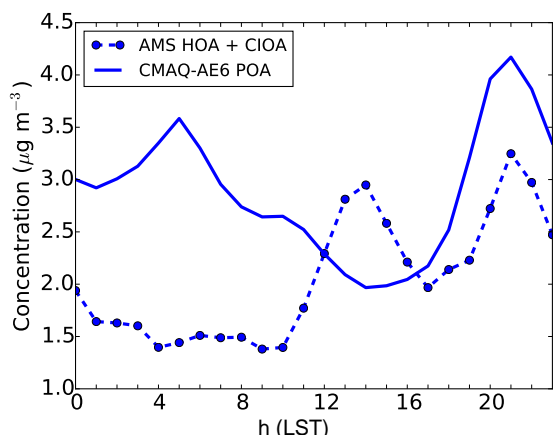

(c) CMAQ-AE6 Primary-like

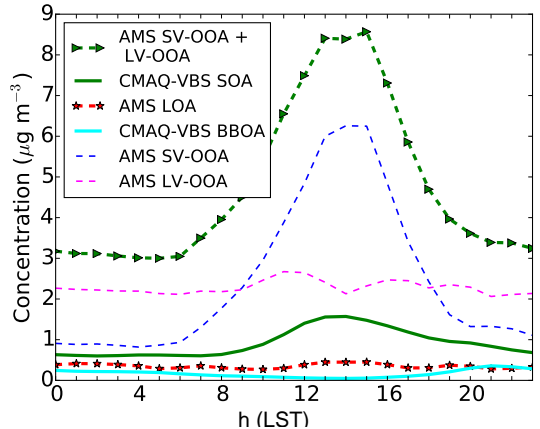

(b) CMAQ-VBS Secondary/OOA-like

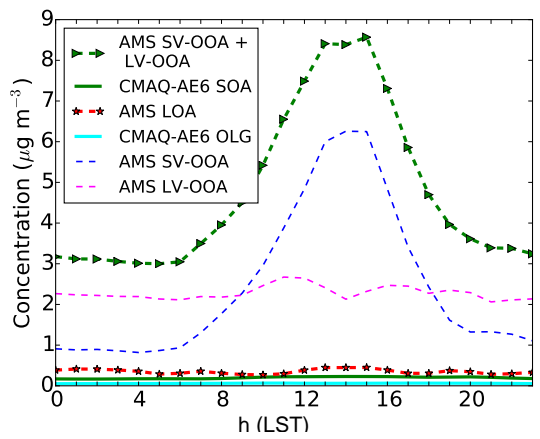

(d) CMAQ-AE6 Secondary/OOA-like

Figure 4. Diurnal profile of AMS-measured PMF OA components against CMAQ-VBS (a, b) and CMAQ-AE6 (c, d) predictions at Pasadena.

et al. (2014), who reported a high non-fossil fraction of OA at the CalNex site on 30 May, corroborate the AMS data. SMOKE/CMAQ emission processing does not allocate more emissions to holidays like Memorial Day for meat cooking, when a larger number of people grill meat and emissions are likely to be higher than normal. Therefore, we would not expect CMAQ to reproduce such events. When the CIOA measurements during the Memorial Day weekend were excluded, the midday and evening AMS peaks were reduced by 0.2 and $0.5 \mu \mathrm{g} \mathrm{m}^{-3}$, respectively, which corresponds to CMAQ-VBS underpredictions of $3.3 \times$ and $2.2 \times$ (or $2.5 \times$ and $1.6 \times$ for nonvolatile emissions and $1.4 \times$ and $1 \times$ for a doubling of CIOA emissions).

Given that the majority of both modeled and measured POA at Pasadena was attributable to cooking sources, further evaluation of the total CIOA emissions as well as the diurnal profile and volatility distribution applied to those emissions may help to improve POA model performance in urban areas.

\subsubsection{Non-cooking POA}

Generally, CMAQ-VBS ncPOA results compared reasonably well against AMS HOA measurements (Fig. 4) in total magnitude, particularly during morning and evening hours. However, modeled ncPOA was biased low, more so in the afternoon. The modeled ncPOA underpredicted the AMS HOA peak (which occurred at 14:00 LST) by a fac- tor of 3 compared to underpredictions of 7-55\% (average of $31 \%$ ) during morning (00:00-10:00 LST) and evening (19:00-23:00 LST) hours. The modeled ncPOA peak instead occurred at night (likely due to the collapse of the planetary boundary layer), which did correspond to a measured evening peak offset by $\sim 1 \mathrm{~h}$.

We calculated that when modeled OA concentrations were increased to match measured OA, partitioning of SVOCs increased ncPOA concentrations by $20 \%$. The $20 \%$ increase in modeled ncPOA corresponded to a $2.3 \times$ underprediction of afternoon ncPOA, with little change to morning and evening performance. When ncPOA was instead treated as nonvolatile, the model overpredicted AMS measurements in the morning and evening (by 1.5 to $1.8 \times$ ) and underpredicted measurements in the afternoon (by 1.5 to $1.6 \times$ ). The resulting diurnal pattern (Fig. S3) was higher in the morning and evening, with a minimum in the afternoon, similar to the more muted diurnal pattern of the semivolatile treatment (Fig. 4a) but opposite the AMS measurements (lower in the morning and evening, peaked in the afternoon).

While neither ncPOA volatility treatment captured the afternoon peak in measured ncPOA, the semivolatile treatment predictions during morning and evening hours suggest it to be the more appropriate model representation of the two. However, further considerations are needed to better account for the AMS-measured midday peak in ncPOA. The measured HOA peak followed a similar pattern to OOA both in 
the diurnal profile (Fig. 4) and on an hourly basis (Fig. 3), which may suggest that photochemistry served a role in the measured HOA peak as additional OA mass attributed to photochemistry could promote partitioning of semivolatile HOA to the particle phase. However, photochemical age and $\mathrm{CO}$ are correlated at this location due to the arrival of downtown LA plume in the early afternoon, so the observed correlation should not be over-interpreted. Alternative aging schemes to the Robinson et al. (2007) approach used in CMAQ-VBS, such as those proposed by Grieshop et al. (2009) and Pye and Seinfeld (2010), generally produce more OA mass than the Robinson et al. (2007) scheme and if applied to primary SVOCs could better represent the ncPOA midday peak (Hayes et al., 2015) assuming the majority of aged primary SVOCs (i.e., oxidized POA) remains as primary SVOCs/POA. These alternative aging schemes may also degrade the morning and evening performance, though Hayes et al. (2015) found the Grieshop et al. (2009) scheme performed reasonably well throughout the day.

Average CMAQ-VBS ncPOA concentrations were approximately a factor of 1.6 lower than AMS-measured HOA values at Pasadena $\left(0.51\right.$ vs. $\left.0.83 \mu \mathrm{g} \mathrm{m}^{-3}\right)$. Increasing the CMAQ-VBS ncPOA emissions by a factor of 1.5 produced average modeled ncPOA concentrations $\left(0.78 \mu \mathrm{g} \mathrm{m}^{-3}\right)$ comparable to the AMS-measured HOA, though the model overpredicted HOA in the morning and evening and underpredicted HOA in the afternoon (Fig. S4). The factor of 1.5-2 underprediction in ncPOA and CIOA, respectively, is similar to the 1.6-2.3 underprediction attributed to low emissions or excessive dispersion for SOA at the Pasadena site (Sect. 3.2.3). If the underprediction were entirely attributable to emissions, these results would suggest that the $2011 \mathrm{NEI}$ underestimates non-cooking-related SVOCs by $\sim 1.5 \times$ and cooking-related SVOCs by $\sim 2 \times$, and therefore our SVOCs emissions are approximately 1.5 to $2 \times$ lower than those estimated using measured HOA at Pasadena in Hayes et al. (2015). However, further work is needed to quantify the role of emissions vs. transport in CMAQ at the Pasadena site.

A source of uncertainty in the ncPOA results is the volatility distribution used for industrial, point, and area sources (i.e., "other" sources) which is based on measurements made from diesel generator exhaust (Robinson et al., 2007). However, we assume that this has less impact on ncPOA predictions than missing emissions since the nonvolatile ncPOA treatment underpredicted the measurements and ncPOA from these sources only comprises $13 \%$ of total modeled POA (or $25 \%$ of ncPOA (Sect. 3.4.1)).

\subsubsection{SOA}

Similar to the routine measurement comparisons of total OC, CMAQ-VBS underpredicted AMS OOA (SV-OOA + LVOOA) (Fig. 4b). This is consistent with many regional air quality studies (Volkamer et al., 2006; De Gouw et al., 2008), including CMAQ (Foley et al., 2010), which often underpre- dict urban SOA. Although those studies are not specific to LA, the similarity of tracer-normalized SOA concentrations across urban areas (e.g., De Gouw and Jimenez, 2009; DeCarlo et al., 2010; Hayes et al., 2015; Zhang et al., 2015) supports the occurrence of a general urban SOA underprediction with models. Other regional models that use high S/IVOC emissions to approximately match the observed POA do match or even exceed the urban observations (e.g., Hodzic et al., 2010; Shrivastava et al., 2011), though we found this not to be the case in CMAQ-VBS. The diurnal pattern of CMAQ-VBS SOA is generally more consistent with measurements of SV-OOA compared to LV-OOA (Fig. 4). The fact that LV-OOA is heavily oxidized and has relatively constant concentrations suggests that it is a background source, comprised of OA formed elsewhere and transported to Pasadena (Hayes et al., 2015). Note, the diurnal profile of CMAQ-AE6 SOA (Fig. 4) formed from particle oligomerization (a process not included in CMAQ-VBS) did follow a similar pattern to AMS LV-OOA (relatively flat throughout the day with a midday/afternoon bimodal peak) but model concentrations were significantly $(\sim 40 \times)$ lower (Fig. S5).

CMAQ-VBS predicted considerably more SOA mass than CMAQ-AE6 $\left(\sim 0.9 \mu \mathrm{g} \mathrm{m}^{-3}\right.$ at Pasadena in CMAQVBS compared to $\sim 0.2 \mu \mathrm{g} \mathrm{m}^{-3}$ for CMAQ-AE6). Overall, CMAQ-VBS SOA diurnal concentrations were approximately 4 to $5.4 \times$ lower than the AMS OOA, with the largest underestimate corresponding to the peak AMS measurement (13:00 LST). The underprediction could be attributed to low emissions, low photochemical age, excessive dispersion or too little transport of emissions to the Pasadena site in the model, or low intrinsic SOA production efficiency.

Comparisons of modeled and measured $\mathrm{CO}$ normalized for background $\mathrm{CO}(\triangle \mathrm{CO}$, where $\triangle \mathrm{CO}=\mathrm{CO}-\mathrm{CO}_{\text {background }}$ and modeled $\mathrm{CO}_{\text {background }}$ $=75 \mathrm{ppb}$; see Hayes et al. (2013) for CO background measurements) show $300 \mathrm{ppb}$ measured $\triangle \mathrm{CO}$ vs. $150 \mathrm{ppb}$ modeled $\triangle \mathrm{CO}$. This observation suggests CMAQ anthropogenic $\mathrm{CO}$ emissions, which are often used as a proxy for anthropogenic emissions, may be a factor of 2 too low, or alternatively that excessive dispersion and/or too low transport of emissions to Pasadena in the model results in the lower modeled CO (see Fig. S6 of the Supplement for CMAQ-VBS CO model performance). Baker et al. (2015), who also used the $2011 \mathrm{NEI}$, reported a similar model underprediction (approximately a factor of 2) for total VOCs at Pasadena. However, Baker et al. (2015) reported the 2011 NEI-based SOA precursor concentrations were in relatively good agreement with measured values, though xylene and toluene were generally overpredicted, which could be attributed to underpredictions in photochemical age leading to insufficient xylene oxidation (e.g., at 0.1 day photochemical age, $\sim 75 \%$ of emitted xylene would remain, but at actual ambient photochemical age a larger fraction would have reacted). CMAQ SOA precursor concentrations were a factor of 1.2 too low compared to $3 \mathrm{~h}$ 
measurements and a factor of 1.1 too high compared to $1 \mathrm{~h}$ measurements (Baker et al., 2015). The slight overprediction of SOA precursor concentrations, along with the factor of 2 underprediction of $\mathrm{CO}$, suggests the SOA precursor to $\mathrm{CO}$ emission ratio was incorrect by a factor of 2 . Comparisons of the ratio of xylene and toluene emissions to $\mathrm{CO}$ emissions in LA and Orange counties against observed xylene and toluene extrapolated to zero photochemical age (to account for photochemistry) to observed $\mathrm{CO}$ support this, as the emissions ratio (0.030) is approximately twice the observed ratio (0.014) and consistent with $\triangle \mathrm{CO}$ being low by a factor of 2 in the model.

The role of photochemical age in underpredictions was explored at Pasadena by examining SOA formed (plotted as SOA / $\triangle \mathrm{CO}$ to approximately correct for differences in emissions and dilution between times) in CMAQ-VBS vs. photochemical age (estimated using $-\log \left(\mathrm{NO}_{x} / \mathrm{NO}_{y}\right)$; Kleinman et al., 2008) (Fig. 5). The slope of the best fit line $\left(66 \mu \mathrm{g} \mathrm{m}^{-3} \mathrm{ppm}^{-1}\right)$ was low by $\sim 1.6 \times$ compared to the measured value of $108 \mathrm{\mu g} \mathrm{m}^{-3} \mathrm{ppm}^{-1}$ (Hayes et al., 2015). However, when the lower $\triangle \mathrm{CO}$ in CMAQ is accounted for, the best estimate for the underprediction is $3.2 \times$. Compared to the measured photochemical age (estimated by $\left.-\log \left(\mathrm{NO}_{x} / \mathrm{NO}_{y}\right)\right)$, the photochemical age component of CMAQ-VBS SOA was low by $\sim 1.5 \times$, which helps explain part of the underprediction in SOA concentrations (Figs. 3 and 4) but not underpredictions of SOA production efficiency (Fig. 5) (i.e., the efficiency per unit precursor at a given age). For reference, Fig. 5 also includes the slope for CMAQ-AE6 predictions $\left(8 \mathrm{~g} \mathrm{~m}^{-3} \mathrm{ppm}^{-1}\right)$, which was much lower than the slope for CMAQ-VBS and also much lower than observations for multiple urban areas (De Gouw and Jimenez, 2009).

Examining modeled SOA vs. odd oxygen $\left(\mathrm{O}_{x} \equiv \mathrm{O}_{3}+\mathrm{NO}_{2}\right)$ (Herndon et al., 2008; Wood et al., 2010), which leverages high measured correlations of SOA and $\mathrm{O}_{x}$ with generally good model performance of $\mathrm{O}_{x}$ (true for Pasadena during CalNex; Kelly et al., 2014), the slope for CMAQ-VBS was $72 \mu \mathrm{gm}^{-3} \mathrm{ppbV}^{-1}$ (Fig. 5). This is approximately a factor of 2 lower than observations at Pasadena $\left(146 \mathrm{\mu g} \mathrm{m}^{-3} \mathrm{ppbV}^{-1}\right)$ (Hayes et al., 2013), where measurements were comparable to other urban areas (Wood et al., 2010; Morino et al., 2014; Zhang et al., 2015). In comparison, CMAQ-AE6 (which has identical $\mathrm{O}_{x}$ concentrations to CMAQ-VBS) underpredicted the metric by a factor of 16 , again suggesting that while CMAQ-VBS underpredicts SOA, it does considerably better than the traditional CMAQ-AE6 SOA treatment. Note, in CMAQ-VBS sensitivity simulations without aging reactions (Sect. 3.4.2) the slope of SOA vs. $\mathrm{O}_{x}\left(11 \mu \mathrm{g} \mathrm{m}^{-3} \mathrm{ppb} \mathrm{V}^{-1}\right)$ was nearly equivalent to the slope of CMAQ-AE6 $\left(9 \mu \mathrm{g} \mathrm{m}^{-3} \mathrm{ppb} \mathrm{V}^{-1}\right)$. This indicates most of the CMAQ-VBS SOA mass was produced as a result of aging of SVOCs and is further discussed in Sect. 3.4.2.

Thus our analysis suggests that the SOA production efficiency in CMAQ-VBS is too low by 1.6 to $2 \times$, photochem- ical age is too low by a factor of $1.5 \times$, and the remaining underprediction (1.6 to $2.3 \times$ ) is attributed to other factors (emissions, transport, etc.). Combining both underestimates of the SOA / $\triangle \mathrm{CO}(1.5 \times$ and $3.2 \times)$ implies that SOA concentrations should be too low by $4.8 \times$, which agrees with the $5.2 \times$ underprediction of SOA compared to AMS OOA.

One possible reason for the underestimation of SOA production efficiency in CMAQ-VBS (and CMAQ-AE6) is that CMAQ SOA yields do not account for SVOC wall loss, which Zhang et al. (2014) indicated can reduce SOA production by 2 to $4 \times$ in chambers. However, the factor of 4 is for alkane systems (speciated long alkanes are not considered SOA precursors in $\mathrm{CB} 05$ ) and toluene and is specific to the smog chamber used in Zhang et al. (2014). Other studies have generally reported lower values, ranging from 1.2 to 4.1 for low- $\mathrm{NO}_{x}$ conditions and 1.1 to 2.2 for high- $\mathrm{NO}_{x}$ conditions (Ng et al., 2007; Chan et al., 2009; Chhabra et al., 2011; Loza et al., 2012; Cappa et al., 2013). Therefore, the 2-4 factor likely represents an upper bound and SVOC wall loss does not likely account for the entire underestimate of SOA production efficiency.

Another possibility for the underprediction of SOA in CMAQ-VBS is SOA formed from missing or mischaracterized (as unspeciated VOCs) IVOC emissions. There is significant uncertainty currently associated with IVOC emissions and their SOA yields. Current CMAQ-VBS IVOC emissions are scaled to primary SVOC emissions $(1.5 \times)$ based on the results of a diesel generator (Robinson et al., 2007) and could potentially be updated to utilize more recent results, such as those reported by Jathar et al. (2014), who indicated unspeciated organics (S/IVOCs) dominated SOA mass formed from combustion emissions. Future work is needed to explore whether better constraining IVOC emissions and yields in CMAQ would help improve model performance, but it would likely not account for the entire missing SOA mass based on sensitivity simulations using upper-bound S/IVOC emissions. In these simulations, S/IVOC emissions were increased by $3.75 \times(\mathrm{SVOC}=1.5 \times \mathrm{POA}$ to match $\mathrm{HOA}$; $\mathrm{IVOC}=1.5 \times \mathrm{SVOC}), 5 \times \quad(\mathrm{SVOC}=2 \times \mathrm{POA}$ to match $\mathrm{CIOA} ; \mathrm{IVOC}=1.5 \times \mathrm{SVOC})$, and $7.5 \times(\mathrm{SVOC}=3 \times \mathrm{POA}$; IVOC $=1.5 \times$ SVOC) but CMAQ continued to underpredict both average (by factors of $4.4 \times, 3.7 \times$, and $2.9 \times$ ) and daily peak (by factors of $4.6 \times, 3.9 \times$, and $2.8 \times$ ) measured OOA. When the factor of $7.5 \times$ is used, the model is in approximate agreement with the observations once the lower model photochemical age and low emissions/excessive dispersion are taken into account, which is consistent with previous modeling efforts for CalNex and elsewhere (Dzepina et al., 2009; Hodzic and Jimenez, 2011; Hayes et al., 2015). However, the approximate agreement may be for the wrong reasons as increased S/IVOC emissions may account for SOA from other missing (or underrepresented) formation pathways and should not be over-interpreted as direct evidence of the presence of SOA formation efficiency of S/IVOCs. 

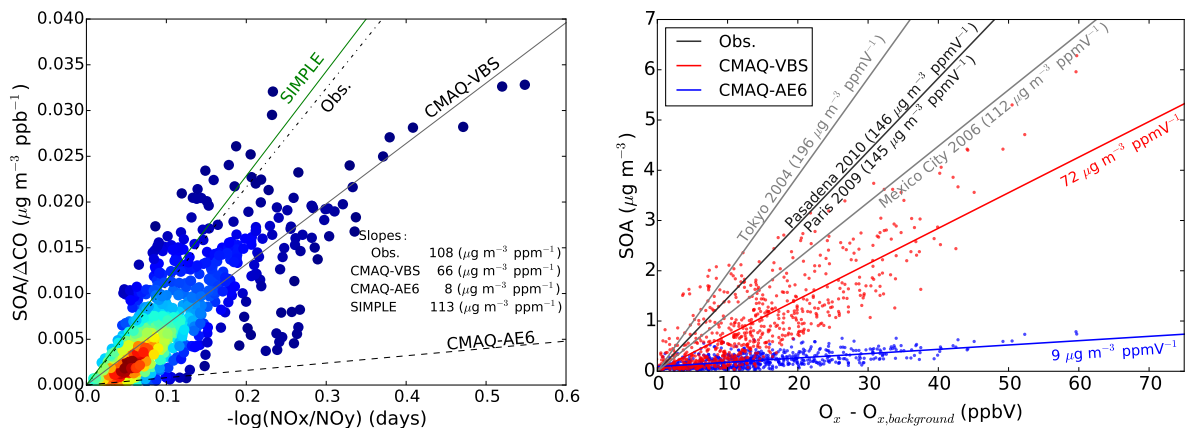

Figure 5. (left) CMAQ-VBS modeled SOA / $\triangle \mathrm{CO}$ vs. photochemical age $\left[-\log \left(\mathrm{NO}_{x} / \mathrm{NO}_{y}\right)\right]$ at Pasadena. Colors indicate the relative density of points determined using the Gaussian density kernel estimate (red corresponds to high density and blue corresponds to low density). Also indicated are the slopes of the best fit lines for the same metric for observations (Hayes et al., 2015), CMAQ-VBS, traditional CMAQ (CMAQ-AE6), and CMAQ with the SIMPLE SOA treatment (Sect. 3.4.3). (right) CMAQ-VBS and CMAQ-AE6 SOA vs. O $\mathrm{S}_{x}\left(\mathrm{O}_{3}+\mathrm{NO}_{2}\right)$ minus $\mathrm{O}_{x}$ background at Pasadena. Also plotted are the slopes of the best fit line for the same metric for observations made from a number of urban areas, including Pasadena.

Note that CMAQ-VBS does not include an oligomerization formation pathway in which heterogeneous/multiphase reactions form SOA (Ziemann and Atkinson, 2012). The lack of this pathway could account for underpredictions in production efficiency though it is plausible the SVOC aging parameterization already accounts for some of the mass formed through oligomerization. CMAQ-AE6, which does include an oligomerization formation pathway (Carlton et al., 2010), estimates that approximately $20-25 \%$ of SOA at Pasadena is comprised of oligomers (Fig. S5); however, because CMAQAE6 significantly underpredictions SOA, this equates to only a small amount of total SOA mass $\left(0.06 \mu \mathrm{g} \mathrm{m}^{-3}\right.$ on average $)$.

\subsection{Non-fossil vs. fossil carbon}

In addition to tracking POA from meat cooking activities separately in CMAQ-VBS, we also added the ability to track POA from gasoline vehicles, diesel vehicles, and "other" sources separately. Tracking POA from various sources provided the opportunity to compare CMAQ-VBS non-fossil vs. fossil carbon contributions against filter-based measurements collected at Pasadena (Fig. 6) (Baker et al., 2015). Those measurements indicated, on average, a near even split of nonfossil $(48 \%)$ and fossil $(52 \%)$ carbonaceous mass (Baker et al., 2015). The Baker et al. (2015) non-fossil measurements were also consistent with other collocated ${ }^{14} \mathrm{C}$ measurements collected during the same time period (51\% nonfossil) (Zotter et al., 2014).

During 6 days the measured non-fossil fraction was $>1$ (values $>1$ ranged from 1.1 to 3.3 ) and therefore measurements on these days were excluded from our analysis as outliers. We believe these outliers were due to a plume from a nearby medical waste incinerator passing directly by the measurement site. The non-fossil fraction estimates assume a non-fossil ${ }^{14} \mathrm{C}$ concentration of $1.2 \times 10^{-12}{ }^{14} \mathrm{C} / \mathrm{C}$ and emissions from medical incinerators, which contain ${ }^{14} \mathrm{C}$, can bias the ${ }^{14} \mathrm{C} / \mathrm{C}$ ratio (Buchholz et al., 2013). Other results were likely also influenced by the incinerator, though to a lesser extent, biasing the non-fossil carbon fraction high.

For the purposes of the comparison, we assumed nonfossil carbon was comprised of biogenic SOC, biomass burning POC, and all meat cooking POC (measurements suggest $\sim 75 \%$ of meat cooking carbon is non-fossil but are likely biased due to imperfections of the PMF analysis; Hayes et al., 2013; Zotter et al., 2014). We assumed fossil carbon was comprised of EC, anthropogenic SOC, POC from gasoline and diesel vehicles, and all POC from "other" emission sources. Non-fossil carbon was always underpredicted in CMAQ-VBS (average predictions of $0.61 \mu \mathrm{g} \mathrm{m}^{-3} \mathrm{vs}$. average observation of $1.86 \mu \mathrm{g} \mathrm{m}^{-3}$ ) (Table 5) and the model predicted it to be dominated by meat cooking emissions. This suggests missing SOA formation pathways, low model SOA yields, or missing emission sources of non-fossil carbon at or upwind of Pasadena, including the substantial likely underestimate of cooking POA discussed above. Higher SOA formation from cooking emissions than parameterized here (Hayes et al., 2015) could account for some of the discrepancy, although this source is poorly characterized. In-basin biogenic SOA (e.g., formed from VOCs emitted within the LA basin) and advection of marine OA are estimated to be very small (Hayes et al., 2015), and they are unlikely to account for the noted discrepancy. Not enough formation and/or advection of biogenic SOA from the north may account for some of the missing non-fossil SOA as well (Hayes et al., 2015).

Contrastingly, CMAQ-VBS did a reasonably good job of predicting fossil carbon at Pasadena (average predictions of $1.81 \mu \mathrm{g} \mathrm{C} \mathrm{m}{ }^{-3}$ vs. average observation of $1.97 \mu \mathrm{g} \mathrm{Cm}^{-3}$ ) (Table 5), though the model tended to underpredict fossil carbon during days with higher measured OOA (e.g., 4 to 10 June; Fig. 3). Fossil carbon was generally dominated by EC and anthropogenic secondary organic carbon 


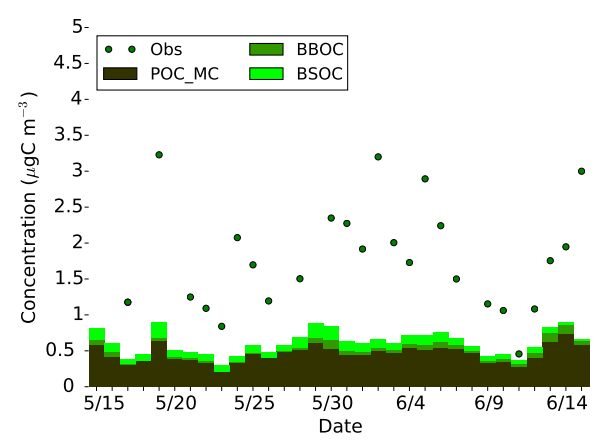

(a) Non-fossil carbon

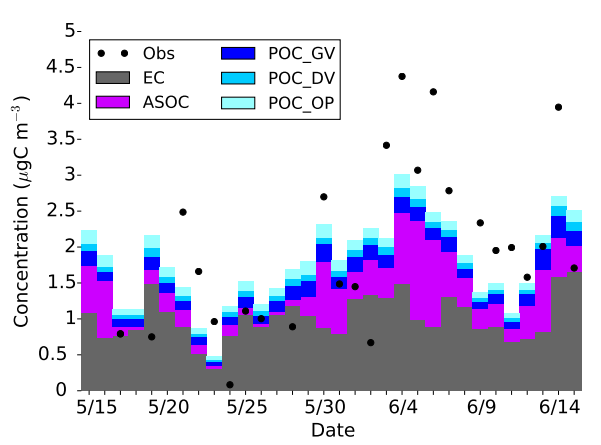

(b) Fossil carbon

Figure 6. Daily average CMAQ-VBS (a) non-fossil and (b) fossil carbon at Pasadena. Non-fossil carbon model species include primary organic carbon from meat cooking (POC_MC), biomass burning OC (BBOC), and biogenic secondary OC (BSOC), while fossil carbon model species include elemental carbon (EC), anthropogenic secondary OC (ASOC), and primary organic carbon from gasoline vehicles (POC_GV), diesel vehicles (POC_DV), and other sources (POC_OP).

(ASOC). Comparisons of CMAQ-VBS EC (which has an identical treatment in CMAQ-AE6) concentrations (average of $1.01 \mu \mathrm{g} \mathrm{m}^{-3}$ ) against CalNex filter-based measurements at Pasadena $\left(0.51 \mu \mathrm{g} \mathrm{Cm}^{-3}\right)$ suggest that CMAQ-VBS (and CMAQ-AE6) overpredicted EC and therefore overemphasizes its contribution to total carbon. Excluding EC, CMAQVBS predicted considerably less non-EC fossil carbon (average of $\left.0.80 \mu \mathrm{g} \mathrm{C} \mathrm{m}^{-3}\right)$ compared to observed $\left(1.46 \mu \mathrm{g} \mathrm{Cm}^{-3}\right)$ (Table 5 and Fig. S7). Additional details regarding the filterbased measurements and the EC / OC split in the NEI are reported in Baker et al. (2015).

Comparisons of the CMAQ-VBS diurnal profiles for nonfossil and fossil carbon at Pasadena against measurements made by Zotter et al. (2014) indicated the model captured the overall pattern of the measurements well (higher non-fossil carbon in the morning and evening with the minimum occurring in the afternoon) but was biased towards fossil carbon (see Fig. S8 of the Supplement). The fact that the model represented the measured diurnal pattern well but was biased suggests that it was missing both non-fossil (in the morning and evening) and fossil sources (in the afternoon). This is consistent with model underpredictions of meat cooking POA (non-fossil) in the morning/evening, minimal contributions from model SOA (non-fossil) throughout the day, and underpredictions of the afternoon peak in anthropogenic SOA (fossil).

\subsection{CMAQ-VBS sensitivity analysis}

\subsubsection{POA source apportionment}

Higher CMAQ-VBS predictions of POA from gasoline vehicles compared to diesel vehicles was true throughout southern California (Fig. 7). Most POA was comprised of meat cooking POA, followed by POA from gasoline vehicles, "other" sources, and finally diesel vehicles. Note that the diesel vehicle panel in Fig. 7 required a scale an order of magnitude lower than the other sources. At Pasadena, POA was comprised of $48 \%$ meat cooking, $18 \%$ gasoline vehicles, $13 \%$ biomass burning (in the form of residential wood combustion), $13 \%$ "other", and $8 \%$ diesel vehicles. This further emphasizes the relative importance of meat cooking activities relative to mobile sources as well as gasoline vehicle emissions compared to diesel vehicle emissions. We note that the predicted urban POA has larger non-fossil than fossil fraction.

Of note was the limited contributions of gasoline and diesel vehicle POC emissions to total carbon at Pasadena, where fossil OC was dominated by ASOC (Fig. 6). This result, coupled with the fact that the majority of ASOC precursor emissions originated from gasoline vehicles and point sources, suggests that gasoline vehicles dominated mobile source OC contributions (Bahreini et al., 2012; Gentner et al., 2012; Ensberg et al., 2014; Hayes et al., 2015).

\subsubsection{Contributions from CMAQ-VBS SOA formation pathways}

As a sensitivity study, the aging of secondary biogenic SVOCs was turned on using the same oxidation pathways used for the aging of secondary anthropogenic SVOCs in CMAQ-VBS. That is, secondary biogenic SVOCs were aged by reactions with $\mathrm{OH}$ in the gas phase using a rate constant of $2 \times 10^{-11} \mathrm{~cm}^{3}$ molec $^{-1} \mathrm{~s}^{-1}$ and each aging step reduced the volatility by an order of magnitude. In the simulation with aging of secondary biogenic SVOCs, SOA concentrations were $\sim 0.5 \mu \mathrm{g} \mathrm{m}^{-3}$ higher throughout the day at Pasadena compared to simulations that did not age secondary biogenic SVOCs (Fig. 8). The diurnal profile indicates aged biogenic SOA concentrations were essentially constant throughout the day, which is the same pattern as AMS LV-OOA. A scenario where LA basin biogenic SOA precursor emissions were zeroed out indicated almost all (95\%) of the predicted biogenic 


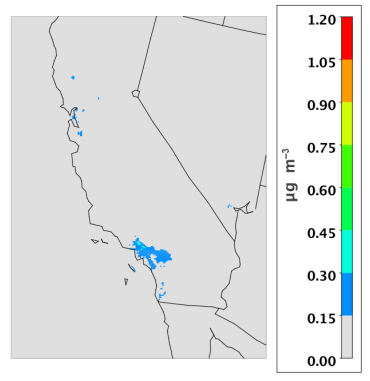

(a) Gas vehicles

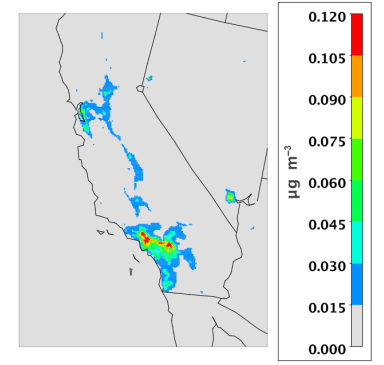

(b) Diesel vehicles

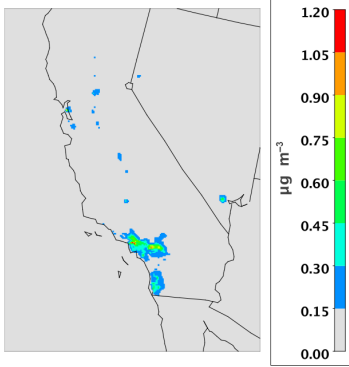

(c) Meat cooking

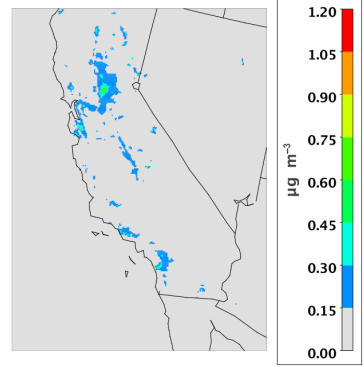

(d) Biomass burning

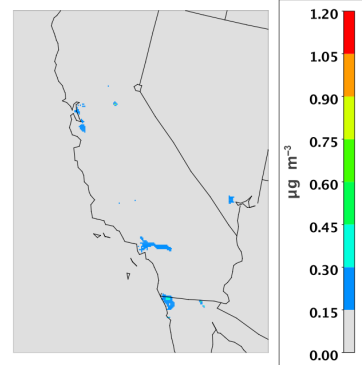

(e) Other

Figure 7. CMAQ-VBS modeled primary OA concentrations from gasoline vehicles (a), diesel vehicles (b), meat cooking (c), biomass burning (d), and "other" sources (e). Note the scale for diesel vehicles is an order of magnitude lower than for other sources.

Table 4. As in Table 3 but for CMAQ-VBS organic carbon (OC) model predictions in sensitivity simulations with aging of biogenic SOA.

\begin{tabular}{llrrrrrr}
\hline Species & Network & $\begin{array}{r}\text { Mean obs. } \\
\left(\mu \mathrm{g} \mathrm{m}^{-3}\right)\end{array}$ & $\begin{array}{r}\text { Mean model } \\
\left(\mu \mathrm{g} \mathrm{m}^{-3}\right)\end{array}$ & $\begin{array}{r}\text { MdnB } \\
\left(\mu \mathrm{g} \mathrm{m}^{-3}\right)\end{array}$ & $\begin{array}{r}\text { MdnE } \\
\left(\mu \mathrm{g} \mathrm{m}^{-3}\right)\end{array}$ & $\begin{array}{r}\text { NMdnB } \\
(\%)\end{array}$ & $\begin{array}{r}\text { NMdnE } \\
(\%)\end{array}$ \\
\hline OC & IMPROVE (247) & 0.71 & 0.42 & -0.25 & 0.27 & -41.8 & 45.0 \\
& CSN (159) & 1.26 & 1.00 & -0.16 & 0.37 & -13.4 & 30.6 \\
\hline
\end{tabular}

Table 5. Comparisons of CMAQ-VBS non-fossil and fossil $\mathrm{C}$ against filter-based measurements $(N=25)$.

\begin{tabular}{lrr}
\hline & $\begin{array}{r}\text { CMAQ-VBS } \\
\left(\mu \mathrm{g} \mathrm{m}^{-3}\right)\end{array}$ & $\begin{array}{r}\text { Obs. } \\
\left(\mu \mathrm{g} \mathrm{m}^{-3}\right)\end{array}$ \\
\hline Non-fossil C & 0.61 & 1.86 \\
Fossil C (with EC) & 1.81 & 1.97 \\
Fossil C (without EC) & 0.8 & 1.46 \\
\hline
\end{tabular}

SOA originated from outside the basin, which is consistent with Hayes et al. (2015).

The additional non-fossil carbon mass from biogenic SOA would help to close the gap in the modeled vs. measured non-fossil carbon at Pasadena. Furthermore, the additional SOA mass improved overall OC model performance at routine monitoring network sites (Table 4) comparable to, if not better, than CMAQ-AE6 model performance. Monoterpene concentrations were underestimated at Pasadena (Baker et al., 2015), although biogenic VOCs emitted in the LA basin make a very small contribution to SOA in Pasadena. Rather, biogenic VOCs emitted in the Central Valley and surrounding mountains are thought to be the major source of biogenic SOA observed in the basin (Hayes et al., 2015). CMAQ-VBS could potentially overestimate biogenic SOA if the underprediction of monoterpene emissions applies to other areas of California. Further evaluation of the impacts of biogenic SOA aging are needed, particularly in areas dominated by biogenic SOA, such as in the southeastern USA.

Figure 8 also provides the contribution of the three standard SOA formation pathways in CMAQ-VBS (VOCs, IVOCs, and aging) to predicted SOA concentrations at Pasadena. These were estimated using sensitivity simulations without IVOCs, aging, or both and then taking the difference between results from the various scenarios. The results indicate the majority of SOA was formed from aging, representing a technique to increase model SOA yields. Although via a different process, the resulting outcome is similar to that obtained whether SOA yields are increased to account for SVOC losses to chamber walls, as proposed by Zhang et al. 


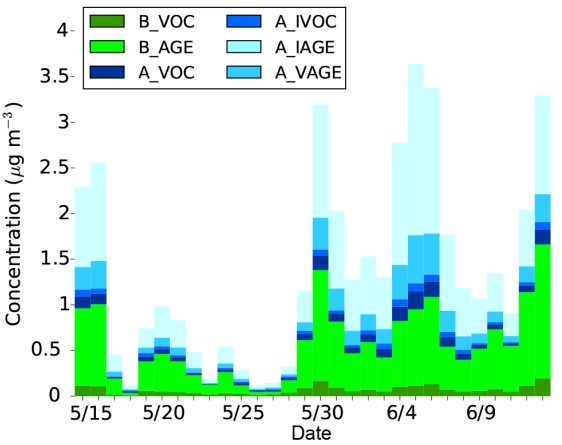

(a) Daily average

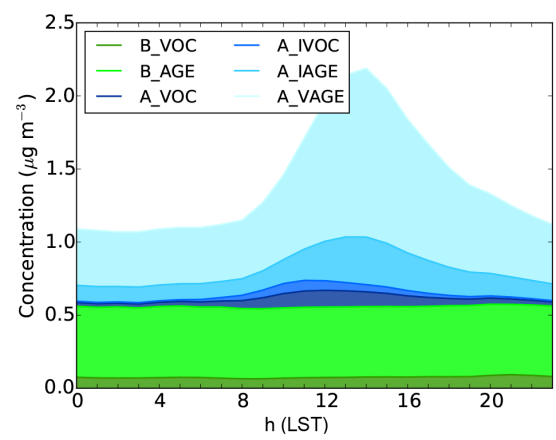

(b) Diurnal profile

Figure 8. Model contributions to SOA at Pasadena from first-product anthropogenic and biogenic VOCs (A_VOC, B_VOC), first-product anthropogenic IVOCs (A_IVOC, B_IVOC), and aging reactions of secondary SVOCs originating from anthropogenic IVOCs (A_IAGE), anthropogenic VOCs (A_VAGE), and biogenic VOCs (B_AGE). Note, the aging of biogenic SVOCs was turned on only during sensitivity simulations.

(2014) and used with CMAQ-AE6 in Baker et al. (2015). Also, although the inclusion of aging reactions leads to an increase in SOA concentrations, the model parameterization may overemphasize the contribution from aging as recent model-to-measurement comparisons with chamber experiments suggested the addition of aging reactions on top of existing parameterizations can lead to overpredictions of SOA concentrations (Zhao et al., 2015). CMAQ-VBS predicted comparable SOA (considering first generation only) from VOCs to CMAQ-AE6, which one would expect given that they produce comparable SOA yields (see Figs. S9-S15 of the Supplement for SOA yield curves). However, the inclusion of higher-volatility semivolatile products $\left(C^{*}\right.$ of 100 and 1000) provides high yielding points along the yield curve missing in Odum two-product framework of CMAQ-AE6. Thus, CMAQ-VBS transfers more mass from VOC precursor to semivolatile oxidation product but requires the aging process to lower the volatility of the semivolatile product to the point of condensing to form SOA.

\subsubsection{Simplified SOA parameterization}

Given the limitations in CMAQ-AE6 and CMAQ-VBS to accurately predict SOA at Pasadena and uncertainty about how best to improve predictions, the question is raised as to whether other parameterizations can improve CMAQ performance in the near term. To this end, we have applied a simplified SOA parameterization (SIMPLE) in CMAQ to provide an alternative SOA modeling budget for comparison with AE6 and VBS. SIMPLE was originally developed by Hodzic and Jimenez (2011) and recently shown to perform well in predicting anthropogenic SOA at Pasadena (Hayes et al., 2015). A key goal of the parameterization is to provide a quick way to estimate the amount of anthropogenic SOA formed from pollution sources, especially for studies in which mechanistic SOA formation description is not the goal, but having the correct amount of aerosol present is im- portant for the results of the simulation. It can also serve as a simple-to-implement benchmark to compare more complex parameterizations across different models. The parameterization uses a single SOA precursor (VOC*) scaled to $\mathrm{CO}$ emissions which reacts with $\mathrm{OH}$. The oxidation product is treated as nonvolatile. In our implementation in CMAQVBS, we use an emission rate of $0.069 \mathrm{~g} \mathrm{VOC}^{*} \mathrm{~g}^{-1} \mathrm{CO}$ and a $k_{\mathrm{OH}}=1.25 \times 10^{-11} \mathrm{~cm}^{3}$ molec $^{-1} \mathrm{~s}^{-1}$, based on the optimum values for Pasadena reported in Hayes et al. (2015). Hayes et al. (2015) found that the SIMPLE parameterization compared favorably to measurements and VBS box model results at Pasadena.

SIMPLE predicted more anthropogenic SOA mass than CMAQ-VBS $(2.5 \times$ more at the afternoon peak) following a similar diurnal cycle (Fig. 9). However, it still underpredicted the AMS-measured SV-OOA by a factor of $2.3 \times$ at the afternoon peak. The slope of SOA / $\Delta \mathrm{CO}$ vs. $-\log \left(\mathrm{NO}_{x} / \mathrm{NO}_{y}\right)$ for SIMPLE was $113 \mu \mathrm{g} \mathrm{m}^{-3} \mathrm{ppm}^{-1}$, which was slightly more than the measured $108 \mu \mathrm{g} \mathrm{m}^{-3} \mathrm{ppm}^{-1}$ and suggests that the SIMPLE parameterization is performing as expected and has an intrinsic SOA formation efficiency consistent with the observations. Underpredictions of photochemical age and low emissions/excessive dispersion most likely explain the observed difference, as $\mathrm{CO}$ was underpredicted both in this study (see the Supplement) and in Baker et al. (2015). The factor of 2 difference in modeled vs. measured $\mathrm{CO}$ indicated in Sect. 3.2.3 are similar to the $2.3 \times$ underprediction in SIMPLE. This shows that the use of SIMPLE in a model can help diagnose model problems that are unrelated to the model intrinsic SOA formation efficiency. CO inventories can also be estimated from ambient data (e.g., Brioude et al., 2013), providing an alternative to bottom-up inventories. 


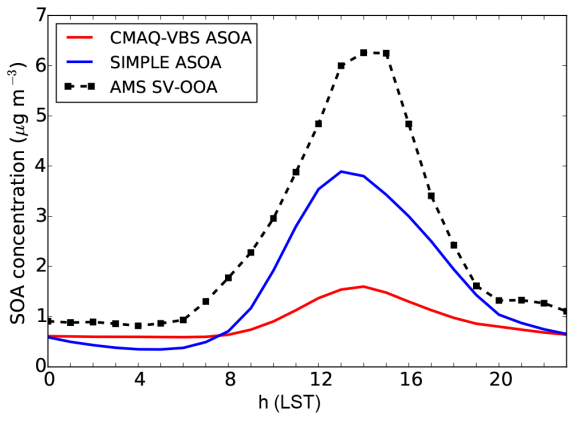

(a) Diurnal profile

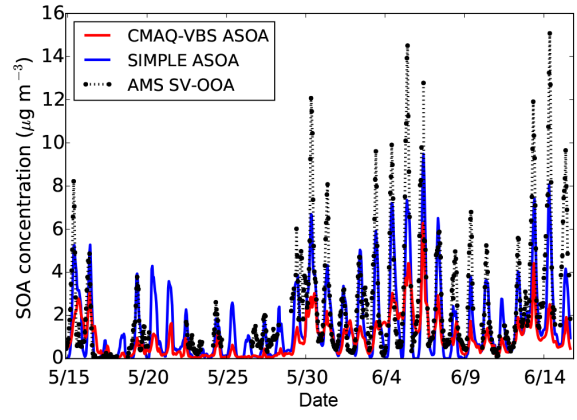

(b) All hours

Figure 9. Comparison of the SIMPLE SOA parameterization in CMAQ to CMAQ-VBS SOA and AMS OOA (a) diurnal cycle and (b) all hours at the Pasadena CalNex site.

\section{Conclusions}

The application of the CMAQ-VBS over California and Nevada in May and June 2010 was found to underpredict OC at routine monitoring networks, likely due to underpredictions of SOA (missing formation pathways, emissions, formation efficiency, etc.). The underprediction of CMAQ-VBS was more pronounced than CMAQ-AE6, particularly at CSN monitors (Table 3) which are primarily located in urban areas and where modeled POA comprised a higher percentage of $\mathrm{OC}$, and therefore likely attributed to the semivolatile treatment of POA in CMAQ-VBS. However, CMAQ-VBS was able to better capture the POA/SOA split, total POA mass, and total SOA mass compared to AMS measurements at Pasadena. CMAQ-VBS predicted less POA (as a result of evaporation) and more SOA (90\% attributed to aging of anthropogenic SOA) compared to CMAQ-AE6.

CMAQ-VBS underpredicted the measured AMS OOA midday peak by $5.4 \times$, albeit to a lesser extent than CMAQAE6 predictions $(38 \times)$. Using two new methods, one based on species ratios and the other based on a simplified SOA parameterization from the observations, we apportioned the SOA underprediction from CMAQ-VBS to too-slow photochemical oxidation based on $\mathrm{NO}_{x}: \mathrm{NO}_{y}(1.5 \times$ lower than observed at Pasadena), too-low intrinsic SOA efficiency (1.6 to $2 \times$ too low for Pasadena), and too-low emissions/excessive dispersion for the Pasadena site (1.6 to $2.3 \times$ too low/high). Individually, none of the recently proposed updates for SOA predictions (SVOC wall loss (Zhang et al., 2014), unspeciated IVOCs (Jathar et al., 2014), aging of biogenic SOA (Donahue et al., 2012), and aging of S/IVOCs) can resolve the model/measurement discrepancy, but a combination of the factors may.

POA at the Pasadena CalNex site was found to be mostly from meat cooking emissions (48\%) and to lesser extents from gasoline vehicle emissions (18\%), diesel vehicle emissions $(8 \%)$, biomass burning $(13 \%)$, and "other" emissions $(13 \%)$ - interestingly more than $50 \%$ from non-fossil (cooking and biomass burning) emissions. Furthermore, the semivolatile treatment of POA better represented the measured AMS diurnal profile of HOA than nonvolatile POA, particularly during morning and evening hours. Using sensitivity simulations, we estimated that the NEI POA captures approximately $50 \%$ of the observed meat cooking SVOCs and approximately $66 \%$ of SVOCs from all other sources. However, CMAQ-VBS underpredictions of POA may also be attributed to the volatility distribution applied to emissions or missing/mischaracterized POA oxidation. A sensitivity simulation suggested increasing CMAQ-VBS SVOC emissions by 1.5 to $2 \times$ would degrade POA model performance in the morning and evening.

Which OA treatment is more appropriate, CMAQ-VBS or CMAQ-AE6, depends on the user's modeling needs and goals. The traditional CMAQ-AE6 treatment, although it has known limitations (generally overpredicting POA and underpredicting SOA), more accurately predicts total OA measured at routine monitoring networks. Conversely, CMAQVBS treats primarily emitted OA as semivolatile and easily incorporates an estimate of IVOC emissions missing from the inventory to provide improved predictions on the total SOA mass and the POA/SOA split at Pasadena. The AE6 approach provides some utility in that parent VOCs and reaction processes are more clearly linked to SOA, which is sometimes useful for scientific and regulatory model applications. Due to the difference in SOA/POA splits, the two CMAQ configurations may respond differently to VOC and/or $\mathrm{NO}_{x}$ emission reductions, which should be examined in future work. Another area for future work is updating the POA emission inventory, originally developed for a nonvolatile POA treatment, to account for semivolatile POA and likely improving CMAQ-VBS total OA predictions.

A future extension of this work includes enhancements to SOA from IVOCs in CMAQ. IVOC emissions are currently scaled to POA. Recent results published by Jathar et al. (2014) provide new insights into how to better estimate IVOC emissions from gasoline and diesel vehicles and biomass burning. With updated IVOC emissions and param- 
eterizations, coupled with comparisons of IVOC measurements made during CalNex (Zhao et al., 2014), CMAQ predictions may be able to close the gap between measured and modeled SOA and provide additional certainty in both IVOCs and the SOA formed from IVOCs.

\section{Information about the Supplement}

In addition to figures and tables already referenced in the text, the Supplement includes additional comparisons of CMAQAE6 and VBS (Fig. S16); comparisons of CMAQ-VBS inorganic aerosols against AMS measurements (Fig. S17); CMAQ-VBS non-fossil and fossil $\mathrm{C}$ at Bakersfield, CA (Fig. S18); CMAQ-VBS SOA contributions at Bakersfield, CA (Fig. S19); volatility distribution of CMAQ-VBS organic aerosols and vapors at Pasadena and Bakersfield (Fig. S20); and CMAQ-VBS modeled $\mathrm{OH}$ diurnal profile at Pasadena (Fig. S21).

\section{The Supplement related to this article is available online at doi:10.5194/acp-16-4081-2016-supplement.}

Acknowledgements. The authors would like to acknowledge John Offenberg of the US EPA and Allan Biedler, Chris Allen, and James Beilder of CSC for their contributions to this work. This project was supported in part by an appointment to the Internship/Research Participation Program at the Office of Research and Development, US Environmental Protection Agency, administered by the Oak Ridge Institute for Science and Education through an interagency agreement between the US Department of Energy and EPA. Patrick L. Hayes and Jose L. Jimenez were partially supported by CARB 11-305 and DOE (BER/ASR) DE-SC0011105.

Disclaimer. Although this work was reviewed by EPA and approved for publication, it may not necessarily reflect official agency policy.

Edited by: K. Tsigaridis

\section{References}

Ahmadov, R., McKeen, S., Robinson, A., Bahreini, R., Middlebrook, A., Gouw, J. D., Meagher, J., Hsie, E.-Y., Edgerton, E., Shaw, S., and Trainer, M.: A volatility basis set model for summertime secondary organic aerosols over the eastern United States in 2006, J. Geophys. Res.-Atmos., 117, D06301, doi:10.1029/2011JD016831, 2012.

Aiken, A. C., Salcedo, D., Cubison, M. J., Huffman, J. A., DeCarlo, P. F., Ulbrich, I. M., Docherty, K. S., Sueper, D., Kimmel, J. R., Worsnop, D. R., Trimborn, A., Northway, M., Stone, E. A., Schauer, J. J., Volkamer, R. M., Fortner, E., de Foy, B., Wang, J., Laskin, A., Shutthanandan, V., Zheng, J., Zhang, R., Gaffney, J., Marley, N. A., Paredes-Miranda, G.,
Arnott, W. P., Molina, L. T., Sosa, G., and Jimenez, J. L.: Mexico City aerosol analysis during MILAGRO using high resolution aerosol mass spectrometry at the urban supersite (T0) - Part 1: Fine particle composition and organic source apportionment, Atmos. Chem. Phys., 9, 6633-6653, doi:10.5194/acp-9-6633-2009, 2009.

Allan, J. D., Williams, P. I., Morgan, W. T., Martin, C. L., Flynn, M. J., Lee, J., Nemitz, E., Phillips, G. J., Gallagher, M. W., and Coe, H.: Contributions from transport, solid fuel burning and cooking to primary organic aerosols in two UK cities, Atmos. Chem. Phys., 10, 647-668, doi:10.5194/acp-10-647-2010, 2010.

Bahreini, R., Middlebrook, A. M., de Gouw, J. A., Warneke, C., Trainer, M., Brock, C. A., Stark, H., Brown, S. S., Dube, W. P., Gilman, J. B., Hall, K., Holloway, J. S., Kuster, W. C., Perring, A. E., Prevot, A. S. H., Schwarz, J. P., Spackman, J. R., Szidat, S., Wagner, N. L., Weber, R. J., Zotter, P., and Parrish, D. D.: Gasoline emissions dominate over diesel in formation of secondary organic aerosol mass, Geophys. Res. Lett., 39, L06805, doi:10.1029/2011GL050718, 2012.

Baker, K. R., Misenis, C., Obland, M. D., Ferrare, R. A., Scarino, A. J., and Kelly, J. T.: Evaluation of surface and upper air fine scale WRF meteorological modeling of the May and June 2010 CalNex period in California, Atmos. Environ., 80, 299309, 2013.

Baker, K. R., Carlton, A. G., Kleindienst, T. E., Offenberg, J. H., Beaver, M. R., Gentner, D. R., Goldstein, A. H., Hayes, P. L., Jimenez, J. L., Gilman, J. B., de Gouw, J. A., Woody, M. C., Pye, H. O. T., Kelly, J. T., Lewandowski, M., Jaoui, M., Stevens, P. S., Brune, W. H., Lin, Y.-H., Rubitschun, C. L., and Surratt, J. D.: Gas and aerosol carbon in California: comparison of measurements and model predictions in Pasadena and Bakersfield, Atmos. Chem. Phys., 15, 5243-5258, doi:10.5194/acp-155243-2015, 2015.

Bey, I., Jacob, D. J., Yantosca, R. M., Logan, J. A., Field, B. D., Fiore, A. M., Li, Q., Liu, H. Y., Mickley, L. J., and Schultz, M. G.: Global modeling of tropospheric chemistry with assimilated meteorology: model description and evaluation, J. Geophys. Res.-Atmos., 106, 23073-23095, 2001.

Brioude, J., Angevine, W. M., Ahmadov, R., Kim, S.-W., Evan, S., McKeen, S. A., Hsie, E.-Y., Frost, G. J., Neuman, J. A., Pollack, I. B., Peischl, J., Ryerson, T. B., Holloway, J., Brown, S. S., Nowak, J. B., Roberts, J. M., Wofsy, S. C., Santoni, G. W., Oda, T., and Trainer, M.: Top-down estimate of surface flux in the Los Angeles Basin using a mesoscale inverse modeling technique: assessing anthropogenic emissions of $\mathrm{CO}, \mathrm{NO}_{x}$ and $\mathrm{CO}_{2}$ and their impacts, Atmos. Chem. Phys., 13, 3661-3677, doi:10.5194/acp-13-3661-2013, 2013.

Buchholz, B. A., Fallon, S. J., Zermeño, P., Bench, G., and Schichtel, B. A.: Anomalous elevated radiocarbon measurements of $\mathrm{PM}_{2.5}$, Nuclear Instruments and Methods in Physics Research Section B: Beam Interactions with Materials and Atoms, 294, 631-635, 2013.

Byun, D. and Schere, K. L.: Review of the governing equations, computational algorithms, and other components of the Models3 Community Multiscale Air Quality (CMAQ) modeling system, Appl. Mech. Rev., 59, 51-77, 2006.

Cappa, C. D., Zhang, X., Loza, C. L., Craven, J. S., Yee, L. D., and Seinfeld, J. H.: Application of the Statistical Oxidation Model (SOM) to Secondary Organic Aerosol formation from photoox- 
idation of $\mathrm{C}_{12}$ alkanes, Atmos. Chem. Phys., 13, 1591-1606, doi:10.5194/acp-13-1591-2013, 2013.

Carlton, A. G. and Baker, K. R.: Photochemical modeling of the Ozark isoprene volcano: MEGAN, BEIS, and their impacts on air quality predictions, Environ. Sci. Technol., 45, 4438-4445, 2011.

Carlton, A. G., Bhave, P. V., Napelenok, S. L., Edney, E. D., Sarwar, G., Pinder, R. W., Pouliot, G. A., and Houyoux, M.: Model representation of secondary organic aerosol in CMAQv4.7, Environ. Sci. Technol., 44, 8553-8560, 2010.

Chan, A. W. H., Kautzman, K. E., Chhabra, P. S., Surratt, J. D., Chan, M. N., Crounse, J. D., Kürten, A., Wennberg, P. O., Flagan, R. C., and Seinfeld, J. H.: Secondary organic aerosol formation from photooxidation of naphthalene and alkylnaphthalenes: implications for oxidation of intermediate volatility organic compounds (IVOCs), Atmos. Chem. Phys., 9, 3049-3060, doi:10.5194/acp-9-3049-2009, 2009.

Chhabra, P. S., Ng, N. L., Canagaratna, M. R., Corrigan, A. L., Russell, L. M., Worsnop, D. R., Flagan, R. C., and Seinfeld, J. H.: Elemental composition and oxidation of chamber organic aerosol, Atmos. Chem. Phys., 11, 8827-8845, doi:10.5194/acp-11-88272011, 2011.

Craven, J. S., Metcalf, A. R., Bahreini, R., Middlebrook, A., Hayes, P. L., Duong, H. T., Sorooshian, A., Jimenez, J. L., Flagan, R. C., and Seinfeld, J. H.: Los Angeles Basin airborne organic aerosol characterization during CalNex, J. Geophys. Res.Atmos., 118, 11453-11467, 2013.

DeCarlo, P. F., Ulbrich, I. M., Crounse, J., de Foy, B., Dunlea, E. J., Aiken, A. C., Knapp, D., Weinheimer, A. J., Campos, T., Wennberg, P. O., and Jimenez, J. L.: Investigation of the sources and processing of organic aerosol over the Central Mexican Plateau from aircraft measurements during MILAGRO, Atmos. Chem. Phys., 10, 5257-5280, doi:10.5194/acp-10-52572010, 2010.

De Gouw, J. and Jimenez, J.: Organic aerosols in the Earth's atmosphere, Environ. Sci. Technol., 43, 7614-7618, 2009.

De Gouw, J., Brock, C., Atlas, E., Bates, T., Fehsenfeld, F., Goldan, P., Holloway, J., Kuster, W., Lerner, B., Matthew, B., Middlebrook, A., Onasch, T., Peltier, R., Quinn, P., Senff, C., Stohl, A., Sullivan, A., Trainer, M., Warneke, C., Weber, R., and Williams, E.: Sources of particulate matter in the northeastern United States in summer: 1. Direct emissions and secondary formation of organic matter in urban plumes, J. Geophys. Res.Atmos., 113, D08301, doi:10.1029/2007JD009243, 2008.

Docherty, K. S., Stone, E. A., Ulbrich, I. M., DeCarlo, P. F., Snyder, D. C., Schauer, J. J., Peltier, R. E., Weber, R. J., Murphy, S. M., Seinfeld, J. H., Grover, B. D., Eatough, D. J., and Jimenez, J. L.: Apportionment of primary and secondary organic aerosols in southern California during the 2005 Study of Organic Aerosols in Riverside (SOAR-1), Environ. Sci. Technol., 42, 7655-7662, 2008.

Donahue, N., Robinson, A., Stanier, C., and Pandis, S.: Coupled partitioning, dilution, and chemical aging of semivolatile organics, Environ. Sci. Technol., 40, 2635-2643, 2006.

Donahue, N., Chuang, W., Epstein, S., Kroll, J., Worsnop, D., Robinson, A., Adams, P., and Pandis, S.: Why do organic aerosols exist? Understanding aerosol lifetimes using the twodimensional volatility basis set, Environ. Chem., 10, 151-157, 2013.
Donahue, N. M., Henry, K. M., Mentel, T. F., KiendlerScharr, A., Spindler, C., Bohn, B., Brauers, T., Dorn, H. P., Fuchs, H.,Tillmann, R., Wahner, A., Saathoff, H., Naumann, K., Möhler, O., Leisner, T., Müller, L., Rennig, M., Hoffmann, T., Salo, K., Hallquist, M., Frosch, M., Bilde, M., Tritscher, T., Barmet, P., Praplan, A., DeCarlo, P., Dommen, J., Prérvôt, A., and Baltensperger, U.: Aging of biogenic secondary organic aerosol via gas-phase $\mathrm{OH}$ radical reactions, P. Natl. Acad. Sci. USA, 109, 13503-13508, 2012.

Dzepina, K., Volkamer, R. M., Madronich, S., Tulet, P., Ulbrich, I. M., Zhang, Q., Cappa, C. D., Ziemann, P. J., and Jimenez, J. L.: Evaluation of recently-proposed secondary organic aerosol models for a case study in Mexico City, Atmos. Chem. Phys., 9, 5681-5709, doi:10.5194/acp-9-5681-2009, 2009.

Ensberg, J. J., Hayes, P. L., Jimenez, J. L., Gilman, J. B., Kuster, W. C., de Gouw, J. A., Holloway, J. S., Gordon, T. D., Jathar, S., Robinson, A. L., and Seinfeld, J. H.: Emission factor ratios, SOA mass yields, and the impact of vehicular emissions on SOA formation, Atmos. Chem. Phys., 14, 2383-2397, doi:10.5194/acp-14-2383-2014, 2014.

Foley, K. M., Roselle, S. J., Appel, K. W., Bhave, P. V., Pleim, J. E., Otte, T. L., Mathur, R., Sarwar, G., Young, J. O., Gilliam, R. C., Nolte, C. G., Kelly, J. T., Gilliland, A. B., and Bash, J. O.: Incremental testing of the Community Multiscale Air Quality (CMAQ) modeling system version 4.7, Geosci. Model Dev., 3, 205-226, doi:10.5194/gmd-3-205-2010, 2010.

Fountoukis, C., Racherla, P. N., Denier van der Gon, H. A. C., Polymeneas, P., Charalampidis, P. E., Pilinis, C., Wiedensohler, A., Dall'Osto, M., O'Dowd, C., and Pandis, S. N.: Evaluation of a three-dimensional chemical transport model (PMCAMx) in the European domain during the EUCAARI May 2008 campaign, Atmos. Chem. Phys., 11, 10331-10347, doi:10.5194/acp11-10331-2011, 2011.

Freutel, F., Schneider, J., Drewnick, F., von der WeidenReinmüller, S.-L., Crippa, M., Prévôt, A. S. H., Baltensperger, U., Poulain, L., Wiedensohler, A., Sciare, J., SardaEstève, R., Burkhart, J. F., Eckhardt, S., Stohl, A., Gros, V., Colomb, A., Michoud, V., Doussin, J. F., Borbon, A., Haeffelin, M., Morille, Y., Beekmann, M., and Borrmann, S.: Aerosol particle measurements at three stationary sites in the megacity of Paris during summer 2009: meteorology and air mass origin dominate aerosol particle composition and size distribution, Atmos. Chem. Phys., 13, 933-959, doi:10.5194/acp-13-933-2013, 2013.

Gentner, D. R., Isaacman, G., Worton, D. R., Chan, A. W. H., Dallmann, T. R., Davis, L., Liu, S., Day, D. A., Russell, L. M., Wilson, K. R., Weber, R., Guha, A., Harley, R. A., and Goldstein, A. H.: Elucidating secondary organic aerosol from diesel and gasoline vehicles through detailed characterization of organic carbon emissions, P. Natl. Acad. Sci. USA, 109, 18318 18323, 2012.

Grieshop, A. P., Logue, J. M., Donahue, N. M., and Robinson, A. L.: Laboratory investigation of photochemical oxidation of organic aerosol from wood fires 1: measurement and simulation of organic aerosol evolution, Atmos. Chem. Phys., 9, 1263-1277, doi:10.5194/acp-9-1263-2009, 2009. 
Hayes, P. L., Ortega, A. M., Cubison, M. J., Froyd, K. D., Zhao, Y., Cliff, S. S., Hu, W. W., Toohey, D. W., Flynn, J. H., Lefer, B. L., Grossberg, N., Alvarez, S., Rappenglück, B., Taylor, J. W., Allan, J. D., Holloway, J. S., Gilman, J. B., Kuster, W. C., de Gouw, J. A., Massoli, P., Zhang, X., Liu, J., Weber, R. J., Corrigan, A. L., Russell, L. M., Isaacman, G., Worton, D. R., Kreisberg, N. M., Goldstein, A. H., Thalman, R., Waxman, E. M., Volkamer, R., Lin, Y. H., Surratt, J. D., Kleindienst, T. E., Offenberg, J. H., Dusanter, S., Griffith, S., Stevens, P. S., Brioude, J., Angevine, W. M., and Jimenez, J. L.: Organic aerosol composition and sources in Pasadena, California, during the 2010 CalNex campaign, J. Geophys. Res.-Atmos., 118, 9233-9257, 2013.

Hayes, P. L., Carlton, A. G., Baker, K. R., Ahmadov, R., Washenfelder, R. A., Alvarez, S., Rappenglück, B., Gilman, J. B., Kuster, W. C., de Gouw, J. A., Zotter, P., Prévôt, A. S. H., Szidat, S., Kleindienst, T. E., Offenberg, J. H., Ma, P. K., and Jimenez, J. L.: Modeling the formation and aging of secondary organic aerosols in Los Angeles during CalNex 2010, Atmos. Chem. Phys., 15, 5773-5801, doi:10.5194/acp-15-5773-2015, 2015.

Henderson, B. H., Akhtar, F., Pye, H. O. T., Napelenok, S. L., and Hutzell, W. T.: A database and tool for boundary conditions for regional air quality modeling: description and evaluation, Geosci. Model Dev., 7, 339-360, doi:10.5194/gmd-7-3392014, 2014.

Herndon, S. C., Onasch, T. B., Wood, E. C., Kroll, J. H., Canagaratna, M. R., Jayne, J. T., Zavala, M. A., Knighton, W. B., Mazzoleni, C., Dubey, M. K., Ulbrich, I., Jimenez, J., Seila, R., de Gouw, J., de Foy, B., Fast, J., Molina, L., Kolb, C., and Worsnop, D.: Correlation of secondary organic aerosol with odd oxygen in Mexico City, Geophys. Res. Lett., 35, L15804, doi:10.1029/2008GL034058, 2008.

Hersey, S. P., Craven, J. S., Schilling, K. A., Metcalf, A. R., Sorooshian, A., Chan, M. N., Flagan, R. C., and Seinfeld, J. H.: The Pasadena Aerosol Characterization Observatory (PACO): chemical and physical analysis of the Western Los Angeles basin aerosol, Atmos. Chem. Phys., 11, 7417-7443, doi:10.5194/acp11-7417-2011, 2011.

Hildebrandt, L., Donahue, N. M., and Pandis, S. N.: High formation of secondary organic aerosol from the photo-oxidation of toluene, Atmos. Chem. Phys., 9, 2973-2986, doi:10.5194/acp-92973-2009, 2009.

Hodzic, A. and Jimenez, J. L.: Modeling anthropogenically controlled secondary organic aerosols in a megacity: a simplified framework for global and climate models, Geosci. Model Dev., 4, 901-917, doi:10.5194/gmd-4-901-2011, 2011.

Hodzic, A., Jimenez, J. L., Madronich, S., Canagaratna, M. R., DeCarlo, P. F., Kleinman, L., and Fast, J.: Modeling organic aerosols in a megacity: potential contribution of semi-volatile and intermediate volatility primary organic compounds to secondary organic aerosol formation, Atmos. Chem. Phys., 10, 5491-5514, doi:10.5194/acp-10-5491-2010, 2010.

Houyoux, M. R., Vukovich, J. M., Coats, C. J., Wheeler, N. J., and Kasibhatla, P. S.: Emission inventory development and processing for the Seasonal Model for Regional Air Quality (SMRAQ) project, J. Geophys. Res.-Atmos., 105, 9079-9090, 2000.

Huang, X.-F., He, L.-Y., Hu, M., Canagaratna, M. R., Sun, Y., Zhang, Q., Zhu, T., Xue, L., Zeng, L.-W., Liu, X.-G., Zhang, Y.H., Jayne, J. T., Ng, N. L., and Worsnop, D. R.: Highly time-resolved chemical characterization of atmospheric submicron particles during 2008 Beijing Olympic Games using an Aerodyne High-Resolution Aerosol Mass Spectrometer, Atmos. Chem. Phys., 10, 8933-8945, doi:10.5194/acp-10-8933-2010, 2010 .

Huffman, J., Docherty, K., Mohr, C., Cubison, M., Ulbrich, I., Ziemann, P., Onasch, T., and Jimenez, J.: Chemically-resolved volatility measurements of organic aerosol from different sources, Environ. Sci. Technol., 43, 5351-5357, 2009.

Jathar, S. H., Gordon, T. D., Hennigan, C. J., Pye, H. O. T., Pouliot, G., Adams, P. J., Donahue, N. M., and Robinson, A. L.: Unspeciated organic emissions from combustion sources and their influence on the secondary organic aerosol budget in the United States, P. Natl. Acad. Sci. USA, 111, 10473-10478, 2014.

Kelly, J. T., Baker, K. R., Nowak, J. B., Murphy, J. G., Markovic, M. Z., VandenBoer, T. C., Ellis, R. A., Neuman, J. A., Weber, R. J., Roberts, J. M.,, Veres, P. R., de Gouw, J. A., Beaver, M. R., Newman, S., and Misenis, C.: Fine-scale simulation of ammonium and nitrate over the South Coast Air Basin and San Joaquin Valley of California during CalNex-2010, J. Geophys. Res.-Atmos., 119, 3600-3614, 2014.

Kim, P. S., Jacob, D. J., Fisher, J. A., Travis, K., Yu, K., Zhu, L., Yantosca, R. M., Sulprizio, M. P., Jimenez, J. L., CampuzanoJost, P., Froyd, K. D., Liao, J., Hair, J. W., Fenn, M. A., Butler, C. F., Wagner, N. L., Gordon, T. D., Welti, A., Wennberg, P. O., Crounse, J. D., St. Clair, J. M., Teng, A. P., Millet, D. B., Schwarz, J. P., Markovic, M. Z., and Perring, A. E.: Sources, seasonality, and trends of southeast US aerosol: an integrated analysis of surface, aircraft, and satellite observations with the GEOS-Chem chemical transport model, Atmos. Chem. Phys., 15, 10411-10433, doi:10.5194/acp-15-10411-2015, 2015.

Kleinman, L. I., Springston, S. R., Daum, P. H., Lee, Y.-N., Nunnermacker, L. J., Senum, G. I., Wang, J., Weinstein-Lloyd, J., Alexander, M. L., Hubbe, J., Ortega, J., Canagaratna, M. R., and Jayne, J.: The time evolution of aerosol composition over the Mexico City plateau, Atmos. Chem. Phys., 8, 1559-1575, doi:10.5194/acp-8-1559-2008, 2008.

Koo, B., Knipping, E., and Yarwood, G.: 1.5-dimensional volatility basis set approach for modeling organic aerosol in CAMx and CMAQ, Atmos. Environ., 95, 158-164, 2014.

Lane, T. E., Donahue, N. M., and Pandis, S. N.: Simulating secondary organic aerosol formation using the volatility basis-set approach in a chemical transport model, Atmos. Environ., 42, 7439-7451, 2008

Loza, C., Chhabra, P., Yee, L., Craven, J., Flagan, R., and Seinfeld, J.: Chemical aging of $\mathrm{m}$-xylene secondary organic aerosol: laboratory chamber study, Atmos. Chem. Phys., 12, 151-167, 2012.

May, A. A., Levin, E. J., Hennigan, C. J., Riipinen, I., Lee, T., Collett, J. L., Jimenez, J. L., Kreidenweis, S. M., and Robinson, A. L.: Gas-particle partitioning of primary organic aerosol emissions: 3. Biomass burning, J. Geophys. Res.-Atmos., 118, 11-327, 2013a.

May, A. A., Presto, A. A., Hennigan, C. J., Nguyen, N. T., Gordon, T. D., and Robinson, A. L.: Gas-particle partitioning of primary organic aerosol emissions: 1 . Gasoline vehicle exhaust, Atmos. Environ., 77, 128-139, 2013b.

May, A. A., Presto, A. A., Hennigan, C. J., Nguyen, N. T., Gordon, T. D., and Robinson, A. L.: Gas-particle partitioning of pri- 
mary organic aerosol emissions: 2. Diesel vehicles, Environ. Sci. Technol., 47, 8288-8296, 2013c.

Mohr, C., DeCarlo, P. F., Heringa, M. F., Chirico, R., Slowik, J. G., Richter, R., Reche, C., Alastuey, A., Querol, X., Seco, R., Peñuelas, J., Jiménez, J. L., Crippa, M., Zimmermann, R., Baltensperger, U., and Prévôt, A. S. H.: Identification and quantification of organic aerosol from cooking and other sources in Barcelona using aerosol mass spectrometer data, Atmos. Chem. Phys., 12, 1649-1665, doi:10.5194/acp-12-1649-2012, 2012.

Morino, Y., Tanabe, K., Sato, K., and Ohara, T.: Secondary organic aerosol model intercomparison based on secondary organic aerosol to odd oxygen ratio in Tokyo, J. Geophys. Res.-Atmos., 119, 13489-13505, 2014.

Murphy, B. N. and Pandis, S. N.: Simulating the formation of semivolatile primary and secondary organic aerosol in a regional chemical transport model, Environ. Sci. Technol., 43, 47224728, 2009.

Ng, N., Kroll, J., Chan, A., Chhabra, P., Flagan, R., and Seinfeld, J.: Secondary organic aerosol formation from $\mathrm{m}$-xylene, toluene, and benzene, Atmos. Chem. Phys., 7, 3909-3922, 2007.

Pye, H. O. T. and Seinfeld, J. H.: A global perspective on aerosol from low-volatility organic compounds, Atmos. Chem. Phys., 10, 4377-4401, doi:10.5194/acp-10-4377-2010, 2010.

Robinson, A. L., Donahue, N. M., Shrivastava, M. K., Weitkamp, E. A., Sage, A. M., Grieshop, A. P., Lane, T. E., Pierce, J. R., and Pandis, S. N.: Rethinking organic aerosols: Semivolatile emissions and photochemical aging, Science, 315, 1259-1262, 2007.

Ryerson, T. B., Andrews, A. E., Angevine, W. M., Bates, T. S., Brock, C. A., Cairns, B., Cohen, R. C., Cooper, O. R., de Gouw, J. A., Fehsenfeld, F. C., Ferrare, R. A., Fischer, M. L., Flagan, R. C., Goldstein, A. H., Hair, J. W., Hardesty, R. M., Hostetler, C. A., Jimenez, J. L., Langford, A. O., McCauley, E., McKeen, S. A., Molina, L. T., Nenes, A., Oltmans, S. J., Parrish, D. D., Pederson, J. R., Pierce, R. B., Prather, K., Quinn, P. K., Seinfeld, J. H., Senff, C. J., Sorooshian, A., Stutz, J., Surratt, J. D., Trainer, M., Volkamer, R., Williams, E. J., and Wofsy, S. C.: The 2010 California Research at the Nexus of Air Quality and Climate Change (CalNex) field study, J. Geophys. Res.-Atmos., 118, 5830-5866, 2013.

Shrivastava, M., Fast, J., Easter, R., Gustafson Jr., W. I., Zaveri, R. A., Jimenez, J. L., Saide, P., and Hodzic, A.: Modeling organic aerosols in a megacity: comparison of simple and complex representations of the volatility basis set approach, Atmos. Chem. Phys., 11, 6639-6662, doi:10.5194/acp-11-66392011, 2011.

Simon, H. and Bhave, P. V.: Simulating the ree of oxidation in atmospheric organic particles, Environ. Sci. Technol., 46, 331-339, 2012.

Skamarock, W. C. and Klemp, J. B.: A time-split nonhydrostatic atmospheric model for weather research and forecasting applications, J. Comput. Phys., 227, 3465-3485, 2008.

Sun, Y.-L., Zhang, Q., Schwab, J. J., Demerjian, K. L., Chen, W.N., Bae, M.-S., Hung, H.-M., Hogrefe, O., Frank, B., Rattigan, O. V., and Lin, Y.-C.: Characterization of the sources and processes of organic and inorganic aerosols in New York city with a high-resolution time-of-flight aerosol mass apectrometer, Atmos. Chem. Phys., 11, 1581-1602, doi:10.5194/acp-11-15812011, 2011.
Tsimpidi, A. P., Karydis, V. A., Zavala, M., Lei, W., Molina, L., Ulbrich, I. M., Jimenez, J. L., and Pandis, S. N.: Evaluation of the volatility basis-set approach for the simulation of organic aerosol formation in the Mexico City metropolitan area, Atmos. Chem. Phys., 10, 525-546, doi:10.5194/acp-10-525-2010, 2010.

US Environmental Protection Agency: 2011 National Emission Inventory, available at: https://www3.epa.gov/ttnchie1/net/ 2011 inventory.html (last access: 15 June 2015), 2014a.

US Environmental Protection Agency: North American Emissions Inventories - Mexico, available at: https://www3.epa.gov/ ttnchie1/net/mexico.html (last access: 10 June 2015), 2014b.

Volkamer, R., Jimenez, J. L., San Martini, F., Dzepina, K., Zhang, Q., Salcedo, D., Molina, L. T., Worsnop, D. R., and Molina, M. J.: Secondary organic aerosol formation from anthropogenic air pollution: rapid and higher than expected, Geophys. Res. Lett., 33, L17811, doi:10.1029/2006GL026899, 2006.

Wood, E. C., Canagaratna, M. R., Herndon, S. C., Onasch, T. B., Kolb, C. E., Worsnop, D. R., Kroll, J. H., Knighton, W. B., Seila, R., Zavala, M., Molina, L. T., DeCarlo, P. F., Jimenez, J. L., Weinheimer, A. J., Knapp, D. J., Jobson, B. T., Stutz, J., Kuster, W. C., and Williams, E. J.: Investigation of the correlation between odd oxygen and secondary organic aerosol in Mexico City and Houston, Atmos. Chem. Phys., 10, 8947-8968, doi:10.5194/acp-10-8947-2010, 2010.

Yarwood, G., Rao, S., Yocke, M., and Whitten, G. Z.: Updates to the Carbon Bond chemical Mechanism: CB05, ENVIRON International Corporation, Novato, CA, 2005.

Zhang, Q., Jimenez, J. L., Canagaratna, M. R., Allan, J. D., Coe, H., Ulbrich, I., Alfarra, M. R., Takami, A., Middlebrook, A. M., Sun, Y. L., Dzepina, K., Dunlea, E., Docherty, K., DeCarlo, P. F., Salcedo, D., Onasch, T., Jayne, J. T., Miyoshi, T., Shimono, A., Hatakeyama, S., Takegawa, N., Kondo, Y., Schneider, J., Drewnick, F., Borrmann, S., Weimer, S., Demerjian, K., Williams, P., Bower, K., Bahreini, R., Cottrell, L., Griffin, R. J., Rautiainen, J., Sun, J. Y., Zhang, Y. M., and Worsnop, D. R.: Ubiquity and dominance of oxygenated species in organic aerosols in anthropogenically-influenced Northern Hemisphere midlatitudes, Geophys. Res. Lett., 34, L13801, doi:10.1029/2007GL029979, 2007.

Zhang, Q. J., Beekmann, M., Freney, E., Sellegri, K., Pichon, J. M., Schwarzenboeck, A., Colomb, A., Bourrianne, T., Michoud, V., and Borbon, A.: Formation of secondary organic aerosol in the Paris pollution plume and its impact on surrounding regions, Atmos. Chem. Phys., 15, 13973-13992, doi:10.5194/acp15-13973-2015, 2015.

Zhang, X., Cappa, C. D., Jathar, S. H., McVay, R. C., Ensberg, J. J., Kleeman, M. J., and Seinfeld, J. H.: Influence of vapor wall loss in laboratory chambers on yields of secondary organic aerosol, P. Natl. Acad. Sci. USA, 111, 5802-5807, 2014.

Zhao, B., Wang, S., Donahue, N. M., Chuang, W., Hildebrandt Ruiz, L., Ng, N. L., Wang, Y., and Hao, J.: Evaluation of OneDimensional and Two-Dimensional Volatility Basis Sets in Simulating the Aging of Secondary Organic Aerosol with SmogChamber Experiments, Environ. Sci. Technol., 49, 2245-2254, 2015.

Zhao, Y., Hennigan, C. J., May, A. A., Tkacik, D. S., de Gouw, J. A., Gilman, J. B., Kuster, W., Borbon, A., and Robinson, A. L.: Intermediate-volatility organic compounds: a large source of 
secondary organic aerosol, Environ. Sci. Technol., 48, 1374313750, 2014.

Ziemann, P. J. and Atkinson, R.: Kinetics, products, and mechanisms of secondary organic aerosol formation, Chem. Soc. Rev., 41, 6582-6605, 2012.
Zotter, P., El-Haddad, I., Zhang, Y. L., Hayes, P. L., Zhang, X. L., Lin, Y. H., Wacker, L., Schnelle-Kreis, J., Abbaszade, G., Zimmermann, R., Surratt, J. D., Weber, R., Jimenez, J. L., Szidat, S., Baltensperger, U., and Prevot, A.: Diurnal cycle of fossil and nonfossil carbon using radiocarbon analyses during CalNex, J. Geophys. Res.-Atmos., 119, 6818-6835, 2014. 